\title{
El ejercicio abusivo de derecho del acreedor y su incidencia en el proceso de ejecución de garantías.
}

\author{
Jose Luis Rodriguez Vallejos ${ }^{1}$
}

\begin{tabular}{ll}
\hline INFORMACIÓN DEL ARTÍCULO & RESUMEN \\
\hline $\begin{array}{l}\text { Historia del artículo: } \\
\text { Recibido el } 10 \text { de junio } 2020\end{array}$ & $\begin{array}{l}\text { La presente investigación tiene como finalidad realizar una adecuada interpretación } \\
\text { del artículo 690-D del Código Procesal Civil, a efectos de incluir el abuso de derecho } \\
\text { como sustento de contradicción de los procesos de ejecución de garantías reales, }\end{array}$ \\
\hline $\begin{array}{l}\text { Palabras clave: } \\
\text { Interpretación }\end{array}$ & $\begin{array}{l}\text { otorgándose así una adecuada tutela jurisdiccional al ejecutado, y generándose un } \\
\text { Abuso de derecho } \\
\text { Contradicción. }\end{array}$
\end{tabular}

The abusive exercise of the creditor's right and its incidence in the process of execution of guarantees

\section{ABSTRACT}

Keywords:

Interpretation,

Abuse of rights

Contradiction.
The purpose of this investigation is to make an adequate interpretation of article 690$D$ of the Civil Procedure Code, in order to include the abuse of law as a basis for contradiction of the processes of execution of real guarantees, thus granting adequate judicial protection to the executed, and generating a systematic judicial criterion for its identification and subsequent sanction.

\section{Sumario}

Introducción. 1. El ejercicio abusivo de derecho, 1.1. Reflexiones generales, 1.2. Características, 1.2.1. De un acto lícito a un acto ilícito, 1.2.2. Concepción subjetiva u objetiva del ejercicio abusivo, 1.2.3. Límite en el ejercicio del derecho subjetivo, 2. El proceso de ejecución de garantías, 2.1. Aspectos esenciales, 2.2. Requerimientos procesales especiales, 2.3. La contradicción en el proceso de ejecución de garantías, 2.3.1. Concepto y naturaleza jurídica, 2.3.2. Causales de contradicción, 3. El ejercicio abusivo de derecho en el proceso de ejecución de garantías, 3.1. ¿Por qué y para qué ocurre?, 3.2. ¿Cuáles son los perjuicios generados a la parte ejecutada?, 3.2.1. El debido proceso, 3.2.2. Consecuencias patrimoniales y extra patrimoniales, 3.3. ¿Cómo se configura el ejercicio abusivo de derecho?, 3.3.1. A partir de la relación sustantiva, 3.3.2. A partir de la relación procesal, 3.3.3. Casuística nacional, 3.4. Propuesta de solución, Conclusiones, Bibliografía.

\footnotetext{
${ }^{1}$ Bachiller en Derecho por la Universidad Católica Santo Toribio de Mogrovejo. Maestrando en la Maestría en Derecho Civil en la Pontificia Universidad Católica del Perú y Máster en Derecho de Daños en Universitat de Girona (Gerona, España). Investigador independiente. Chiclayo, Perú. Email: jose.rodriguezv@pucp.edu.pe, ORCID: https://orcid.org/0000-0002-6447-8949
} 
Introducción

La relación entre los sujetos de derecho debe encontrarse en un contexto de buena fe, es decir, ciñendo sus conductas a valores como la confianza, lealtad, credibilidad, razonabilidad, solidaridad, entre otros. Se trata de un principio matriz, del que se deriva el ejercicio abusivo del derecho, siendo este último un principio reconocido en la Constitución y Código Civil peruano. La controversia se suscita en cuanto a que, una vez realizada la identificación del acto ilícito que constituye un ejercicio abusivo de derecho, es necesario dotar de protección al titular de la situación jurídica subjetiva afectada. Se representa un peligro de lesividad mayor, o concreción de este, si se tiene en cuenta que no existe una tutela específica regulada en una norma jurídica. Dado ese vacío adjetivo, el Juez debe recurrir a criterios indeterminados en el caso en concreto, que bien pudiera ofrecerle la ley, jurisprudencia y doctrina, a efectos de contrarrestar las consecuencias de unacto abusivo. Es necesario avocarse a la proscripción de un ejercicio abusivo de derecho del acreedor en el proceso de ejecución de garantías reales, debiéndose generar un criterio judicial que pueda replicarse en otros casos, interpretando adecuadamente la norma procesal e identificando el acto configurativo; máxime si no se trata de un proceso de conocimiento para evidenciar con claridad tal pretensión irregular. El tema bajo estudio se encuentra en conocimiento de los operadores jurídicos, en lo que respecta al "abuso de derecho", pues es una institución muy tratada en la doctrina; empero es necesario avocarse a la proscripción de un ejercicio abusivo de derecho del acreedor en el proceso de ejecución de garantías reales, lo cual no resulta una materia analizada en la doctrina, debiéndose generar un criterio judicial que pueda replicarse en otros casos.

\section{EL EJERCICIO ABUSIVO DE DERECHO}

\subsection{Reflexiones generales}

Después de un estudio de las fuentes de derecho en Roma, Fernández (1992) concluye que en la época antigua no es claro o preciso advertir la existencia de una teoría general del abuso del derecho, pues "los prudentes juristas romanos abordaron y resolvieron, dentro del principio de la equidad, cuestiones muy concretas en las cuales percibieron ciertos matices de un uso anormal de los derechos" (p. 98). Tampoco en la edad media se aprecia la creación o empleo de un principio jurídico relacionado al ejercicio abusivo de derecho (o comúnmente denominado abuso de derecho).

Entonces, como menciona Obando (2017), el surgimiento de la figura del abuso de derecho se dio mediante una creación jurisprudencial francesa en la segunda mitad del siglo XIX y comienzos del siglo XX, siendo recogido posteriormente por los ordenamientos jurídicos nacionales. A decir de Fernández (1992), con el paso del tiempo los jueces franceses entendieron la necesidad de armonizar el derecho subjetivo con el interés social, pues la comunidad y la conciencia jurídica colectiva advertían que la legislación vigente consagraba prerrogativas a favor del individuo sin límite alguno:

La jurisprudencia francesa, dentro de este contexto, intenta atenuar los "excesos" cometidos por los individuos en la "legítima" actuación de sus derechos subjetivos, así como reparar los perjuicios irrogados con tal comportamiento. De este modo, se producen las primeras aproximaciones a lo que, con el correr del tiempo, se convertiría en la autónoma y discutible figura del abuso del derecho. (p. 108)

En ese orden histórico, las sentencias de Colmar y de Lyon, de 1855 y 1856, respectivamente, establecen la figura del abuso del derecho frente al, hasta ese entonces, absolutismo de los derechos subjetivos. Los jueces enuncian que el ejercicio del derecho subjetivo tiene como límite la satisfacción de un interés serio y legítimo. Asimismo, fijan como criterio general la valoración del comportamiento humano, desde el punto de vista moral, sicológico, económico o social, para identificar la conducta constitutiva del abuso de derecho.

El "abuso del derecho" ha sido tratado desde sus inicios como un componente de la responsabilidad civil, a tal punto que la jurisprudencia francesa no se limitó a contrarrestar el ejercicio abusivo del derecho; por el contrario, dejaba a salvo el derecho del accionante para solicitar el resarcimiento del daño causado. Sin embargo, en la actualidad, es considerado como una institución perteneciente a la teoría general del derecho, de tal manera que puede ser aplicado al ámbito civil, procesal civil, comercial, administrativo, entre otros. Tal idea es desarrollada por Loutayf (2015): Se trata de un postulado general, con aspectos comunes, y otros específicos según la rama a que se refiera. El hecho que haya sido desarrollada particularmente por el Derecho civil no importa apropiación del instituto, ni significa que resulte inaplicable a las demás ramas del Derecho; en todo caso, en cada materia presentará sus variantes propias. (p. 13)

El Código Civil peruano de 1936 fue el primero, al menos en Latinoamérica, en acoger la expresión "abuso del derecho", ubicándolo en su Título Preliminar, en clara alusión a que la Ley no ampara el abuso del derecho. Esta fórmula legal ha sido modificada con el actual texto 
del Código Civil de 1984 solo respecto a su literalidad, puesto que en esencia es lo mismo.

Aproximándonos a una definición, sostenemos que el abuso de derecho, entendido con mayor claridad como el ejercicio abusivo del derecho, es un evento jurídico particular manifestado en una conducta humana, sea activa u omisiva, y en base a un derecho subjetivo, que se configura en un ilícito al lesionar un deber jurídico genérico, sin importar el daño causado y la intencionalidad que tuvo el agente a quien se le atribuye la acción.

\subsection{Características}

El concepto de abuso es difícil de definir de manera literal, porque decir solamente que abuso es el uso u omisión excesiva y arbitraria de un derecho, no es una descripción que agote el contenido de este término. Una lectura literal del artículo II del Título Preliminar del Código Civil ${ }^{2}$ y 103 de la Constitución peruana ${ }^{3}$ no aporta mucho a la definición del ejercicio abusivo de derecho. Entonces es necesario presentar sus características esenciales, con la finalidad de comprender de mejor manera esta institución.

\subsubsection{De un acto lícito a un acto ilícito}

La ilicitud, según Espinoza (2015), se configura con la transgresión de una norma jurídica, o cuando se contravienen los valores de la convivencia social, generándose situaciones de injusticia. En otras palabras, el acto ilícito es un acto prohibido por el ordenamiento jurídico, pues se lesionan deberes generales.

Sostenemos que el ejercicio de un derecho subjetivo es un acto perteneciente al campo de la licitud. Empero, cuando se transgreden normas fundamentales de convivencia social en la ejecución de este acto, se le ubica en el ámbito de la ilicitud. El ejercicio abusivo de un derecho implica traspasar el límite de la licitud por contravenirse un principio general del derecho, perjudicándose el interés ajeno. En el mismo sentido se pronuncia Rubio (2008):

Así, el abuso del derecho consistiría en un acto en principio lícito, pero que por una laguna específica del Derecho es tratado como no lícito al atentar contra la armonía de la vida social. Tal calificación no proviene ni de la aplicación de las normas sobre responsabilidad civil, ni de otras normas expresas restrictivas de la libertad, sino que se realiza por el juez aplicando los métodos de integración jurídica. (p. 29)

${ }^{2}$ Artículo II del Título Preliminar del Código Civil: "La ley no ampara el ejercicio ni la omisión abusivos de un derecho. Al demandar indemnización u otra pretensión, el interesado puede solicitar las
1.2.2. Concepción subjetiva u objetiva del ejercicio abusivo

Pabón y Mora (2014) sostienen que el ejercicio abusivo del derecho debe cometerlo el titular de este, presentándose dos supuestos: se configura con la intención de dañar a otro (responsabilidad por conducta dolosa), o con la negligencia, impericia o imprudencia del titular del derecho, traspasando sus límites. Esta expresión resume la concepción subjetiva que caracteriza al ejercicio abusivo del derecho.

Dentro del sistema o concepción subjetiva, se ha comprendido el ejercicio abusivo desde la intencionalidad del agente, es decir, cuando se advierte que el titular del derecho tiene la intención de perjudicar el interés del prójimo. En ese contexto, Moisset (2002) expone que "se trata, pues, de una actitud dolosa de quien ejercita las prerrogativas o facultades que surgen de la norma con el propósito de causar daño a un tercero" (p. 27). Sin embargo, desde esta perspectiva, se critica la dificultad para probar el dolo o la intención de generar perjuicio en terceros.

En el mismo sistema subjetivo, el ejercicio abusivo del derecho también es apreciado desde la negligencia del agente. Aquí ya no es posible referirse al dolo. Al contrario, la conducta abusiva se presenta sin que haya ánimo, intención o interés del titular del derecho de generar un perjuicio al resto. Moisset (2002) concuerda con esta idea:

Un segundo sistema, expuesto por muchos autores franceses y aceptado frecuentemente en la jurisprudencia de ese país, requiere solamente que el actuar del sujeto, al ejercitar su derecho y ocasionar con ello un perjuicio a otro, sea de carácter culposo; no se exige ya la prueba de la "intención" de perjudicar, sino que basta la conducta negligente. (p. 28)

En cambio, la concepción objetiva permite apreciar el ejercicio abusivo del derecho desde otra óptica: la vulneración de la finalidad o funcionalidad del derecho subjetivo. Fernández (1992) sostiene que esta posición aparece con el propósito de superar las deficiencias del sistema subjetivo:

Según esta tendencia, el abuso del derecho no se definiría por la intención de perjudicar de parte del titular del derecho, por la presencia de la culpa o por la ausencia de un interés serio y legítimo, sino más bien por la gravitación de un elemento objetivo, como es el manifiesto ejercicio anormal de un derecho subjetivo. Así, ya no se trataría de indagar fundamentalmente por las intenciones del sujeto, por la ausencia de un interés

medidas cautelares apropiadas para evitar o suprimir provisionalmente el abuso".

${ }^{3}$ Artículo 103 de la Constitución peruana: “(...) La Constitución no ampara el abuso del derecho". 
serio y legítimo o de un beneficio personal, sino que para identificar el abuso del derecho se aplicaría un criterio de carácter objetivo como es el de la función o finalidad socio-económica de cada derecho. (p. 129) También es ilustrativa la descripción de este sistema realizada por Loutayf (2015), quien menciona que el ejercicio anormal de un derecho no se limita al criterio finalista o funcional, añadiendo el criterio ético, basado en la vulneración de la buena fe, moral y buenas costumbres. Este autor añade otro aspecto dentro de la concepción objetiva: la ruptura del equilibrio de intereses de los sujetos vinculados a partir de la conducta del agente.

Con el fin de apaciguar esta doble visión del ejercicio abusivo de derecho, se plantea su comprensión conjunta (no se oponen, sino se complementan), atribuyéndose al juez el deber de determinar su configuración en cada caso concreto. Fernández (1992) expone qué situaciones debe valorar el juez para condenar el ejercicio abusivo de derecho:

El juez debería tener en consideración la existencia de diversas situaciones, como son: 1) la intención de dañar; 2) ausencia de interés; 3 ) si se ha elegido, entre varias maneras de ejercer el derecho, aquella que es dañosa para otros; 4) si el perjuicio ocasionado es anormal o excesivo; 5) si la conducta o manera de actuar es contraria a las buenas costumbres; 6) si se ha actuado de manera no razonable, repugnante a la lealtad y a la confianza recíproca. Habría que añadir, además, que el magistrado debe tener en cuenta si el comportamiento del agente no concilia con la finalidad económico-social del derecho que la ley le concede. (pp. 134-135).

\subsubsection{Límite en el ejercicio del derecho subjetivo}

El ejercicio de un derecho subjetivo tiene como límite diversos deberes jurídicos, siendo uno de ellos el de una actuación conforme a la buena fe. Esta se puede definir, también, con las expresiones de confianza, lealtad, comportamiento normal y ausente de fines ulteriores, sinceridad, asistencia, razonabilidad, colaboración, entre otras.

No todas las definiciones son, sin embargo, coincidentes porque, por ejemplo, el "deber de asistencia y fraternidad", que solo es reconocido por un autor (Corfu), responde a una idea de contrato muy alejada del modelo clásico-confrontacional. Los demásautores, en cambio, no parecen llegar tan lejos, limitándose a señalar ciertos valores como la lealtad y la confianza que, a diferencia de la "asistencia y fraternidad", sí son compatibles con algunas tendencias del modelo clásico de contrato, que toleran una exigencia moderada de buena fe. (Zusman, 2005, p.23)
Puede deducirse, entonces, que la buena fe tiene una definición compleja, más aun si los tratadistas omiten pronunciarse acerca de ciertos modelos, estando en vigencia que la buena fe denota en realidad un hombre honrado universal.

El Código Civil peruano reconoce a la buena fe de forma expresa en los artículos 168 u 1362, en referencia a que los actos jurídicos deben interpretarse de acuerdo al principio de la buena fe, y los contratos se negocian, celebran y ejecutan según las reglas de la buena fe y común intención de las partes. Sin embargo, si bien la buena fe tiene una definición compleja, sí se pueden asumir conceptos generales, como es el caso de Obando (2017), quien expone que "la buena fe expresa la confianza y esperanza en una actuación correcta de otro. La buena fe objetiva (comportamiento); la buena fe subjetiva (creencia)" (p. 97).

Conforme se aprecia de nuestra regulación jurídica nacional, la naturaleza del abuso de derecho es la de un principio general del derecho, ligado indudablemente al principio matriz o base de la buena fe. Así, no solo tiene asidero en la doctrina o jurisprudencia, sino también se encuentra consagrado principalmente en el artículo 103 de la Constitución peruana, y el artículo II del Título Preliminar del Código Civil de forma expresa.

Aunado a ello, de acuerdo a su naturaleza, el abuso de derecho en una relación jurídica no se condice necesariamente en las disposiciones legales o el derecho positivo; importa, en todo caso, una trasgresión a los cimientos del ordenamiento jurídico, refiriéndonos a los valores de justicia, seguridad, buena fe, solidaridad y moral. De allí que deba precisarse que una conducta puede encontrarse conforme a un artículo de la Ley, pero resulta evidente su contrariedad a los principios generales del derecho que inspiran el sistema jurídico nacional.

Se entiende que el mercado es una búsqueda dinámica $y$, ciertamente, agresiva del propio interés, no pudiendo funcionar sin una lealtad básica. "La buena fe, dentro de su acepción clásica de honestidad fundamental, de razonable inocencia y de coherencia en la actuación es, sin duda, un principio esencial dentro del Derecho moderno" (De Trazegnies, 2005, p. 37). De allí que, justamente sin buena fe, el Derecho se configuraría en una regla de juego no respetada.

Está claro que los valores jurídicos, como la justicia, seguridad, solidaridad y otros, se subsumen en una vida en colectividad; esto es, dentro de una comunidad de personas existe una conciencia jurídica colectiva de que esto es así. Fernández (1992) menciona:

La conciencia jurídica colectiva reclama, en términos generales y más allá de la vigencia de normas específicas dentro del ordenamiento positivo, el que en 
las relaciones humanas intersubjetivas se vivencien los valores ínsitos en los principios generales del derecho, como el de la buena fe, el orden público y el de las buenas costumbres. (p. 28)

La exigencia social o comunitaria es, entonces, que los comportamientos humanos sociales efectivamente se subsuman o adecuen en los principios generales del derecho, pudiéndose determinar qué conductas están prohibidas o permitidas en relación a una temática axiológica.

\section{EL PROCESO DE EJECUCIÓN DE GARANTÍAS}

\subsection{Aspectos esenciales}

El proceso de ejecución de garantías reales ha merecido un tratamiento diferenciado no tanto por la particularidad de determinar el título ejecutivo, sino porque la obligación objeto de satisfacción en el proceso ejecutivo tiene a su favor una garantía de naturaleza real, esto es, una garantía hipotecaria o mobiliaria (también conocida como prenda). A efectos de mayor ilustración, Ledesma (2010) ha sostenido lo siguiente:

El proceso de ejecución de garantía es aquella acción que corresponde al titular del derecho real para hacer efectiva la venta de la cosa, por incumplimiento en la obligación garantizada, lo que se despacha en virtud de un título de ejecución que debe contener un derecho cierto, expreso y exigible (ver artículo 689 CPC). (p. 73) En ese escenario, el proceso judicial señalado constituye uno de característica especial, al haberse regulado al margen del proceso único de ejecución, aunque aplicando sus disposiciones generales; $y$ también es procedente para todo tipo de acreedor (sea persona natural o jurídica) que tenga un derecho a su favor reconocido en un título ejecutivo y que, a su vez, se encuentre garantizada con una hipoteca o prenda. Así, Ariano (2016) ha indicado que el Código Procesal Civil de 1993 introdujo un procedimiento de ejecución de garantías novedoso, en el entendido que era la primera vez en la historia procesal del Perú que aquel era especial y general a la vez, pues difirió del procedimiento general de ejecución y no previó para una clasificación especial de acreedores, sino que cualquier acreedor que tenga una obligación garantizada podía acudir a la vía judicial para interponer su pretensión ejecutiva.

El proceso de ejecución de garantías reales ha ido variando en cuanto a su estructura y funcionamiento por políticas de Estado. En relación a la garantía mobiliaria, en el año 2006 hubo la dación de la Ley 28677, Ley de Garantías Mobiliarias, estableciéndose un mecanismo extrajudicial ejecutivo, sin que de por medio haya intervención de un juez; de igual modo, con el actual Decreto Legislativo N. 1400 que aprueba el régimen de garantía mobiliaria y sustituye a la Ley 28677, se mantiene la idea de una ejecución judicial o extrajudicial de la garantía mobiliaria, pudiendo recurrirse a la vía judicial-proceso sumarísimo para la incautación del bien afectado con el gravamen.

Los cambios más importantes se realizaron con la promulgación del Decreto Legislativo N. 1069 con fecha 28 de junio del 2008, pues modificó el Código Procesal Civil para permitir, en primer lugar, que la persona que constituyó la garantía real sea parte del proceso como litisconsorte necesario, así como notificar a terceros que tengan la posesión del bien materia de ejecución. En segundo lugar, acrecentó la defensa del ejecutado, dado que le permitía alegar como supuesto de contradicción la falsedad del título ejecutivo, adicionándose que era posible ofrecer como medios de prueba la declaración de parte y pericia. En tercer lugar, se introdujo una medida que es acorde al principio de economía procesal, pues permitía que el saldo adeudado, luego de producida la ejecución del bien en garantía y el pago al ejecutante, pueda ser ejecutado en el mismo procedimiento, sin necesidad de iniciarse otro proceso para el cobro de la acreencia que no pudo ser cubierta con el bien en garantía.

Sobre el objeto del presente proceso, y conforme a lo antes expuesto, es posible entender en primer orden, que si bien es cierto el proceso de ejecución de garantías se circunscribe a la ejecución forzosa del bien en garantía, también lo es que la puesta en funcionamiento del órgano jurisdiccional se debe al interés del ejecutante de ver satisfecho su derecho de crédito reconocido en un título ejecutivo.

\subsection{Requerimientos procesales especiales}

El actual texto del artículo 720 del Código Procesal Civil enumera un conjunto de requisitos para la procedencia del proceso de ejecución de garantías. Con el primer numeral se pretende que la constitución de la garantía real satisfaga las formalidades establecidas por la norma sustantiva, y la obligación garantizada esté consignada en el documento de la constitución de la garantía real, o se ubique en otro título ejecutivo. Por ejemplo, puede ser el caso de una hipoteca constituida con escritura pública y el contrato de mutuo contenido en ella; o también, tratándose de una hipoteca sábana (obligaciones futuras), se adjunte en el proceso un pagaré que acredita la existencia de la obligación garantizada.

Una cuestión de debate en los procesos de ejecución de garantías reales, y que guarda relación con el numeral mencionado, es determinar cuál o cuáles son los documentos que constituyen título ejecutivo. El Sexto 
Pleno Casatorio Civil ha establecido en sus consideraciones sobre el caso -de una manera poco clara o fundamentada- que hay una suerte de título compuesto, constituido por el documento que contiene la garantía real y el estado de saldo deudor, adicionándose, de ser el supuesto, otro título ejecutivo que consigne la obligación garantizada si es que esta no se halla en el documento de la garantía real. Con tal premisa, cabría entender que en los casos donde la obligación garantizada se encontrara, por ejemplo, en un título valor, la ejecución se realizaría en virtud de tres títulos ejecutivos, ejerciéndose la acción cambiaria. Así concluyen los magistrados suscribientes en el citado pleno al sostener en el fundamento cincuenta y nueve que:

Es absurdo considerar que cuando la obligación está contenida en un título valor y se pretende la ejecución de la garantía (sábana o no) no se ejercita la "acción cambiaria" (rectius, cartular): la acción cambiaria (rectius, cartular) implica el ejercicio del derecho incorporado al documento, nada más.

Sin embargo, tal criterio resulta contradicho tres años después con la Casación 1930-2015-Arequipa expedida con fecha cuatro de abril del dos mil dieciséis, al indicar el propio Colegiado Supremo que en innumerables ocasiones ha sostenido que el proceso de ejecución de

garantías reales se promueve en virtud del título de ejecución constituido por el documento que contiene la garantía y el estado de cuenta de saldo deudor. Asimismo, en el fundamento sexto expone lo siguiente: (...) la obligación que se está garantizando conste en el mismo documento que contiene la constitución de la garantía real o en todo caso en cualquier otro título ejecutivo, lo cual no supone, en este último supuesto que se esté exigiendo que se verifique si tal título confiere acción cambiaria o no, ya que solamente está regulando que la fuente de la obligación de donde deriva la constitución de la garantía real aparezca anotado en uno $u$ otro documento antes mencionados, que en caso se trate de un título ejecutivo, aquel debe ser considerado como un medio probatorio que coadyuvará al amparo de la pretensión que se instaure en el marco de un proceso de

\footnotetext{
${ }^{4}$ La jurisprudencia nacional ha desarrollado que el estado de cuenta de saldo deudor forma parte del título ejecutivo en virtud del cual se promueve el proceso de ejecución de garantías. Sin embargo, es necesario advertir que aquel, de forma independiente, no tiene mérito ejecutivo si es que han sido emitidas por sujetos de derecho que no pertenecen al sistema financiero, ni tampoco puede ser reconocido así mediante un pronunciamiento judicial, dado que existe una reserva legal para ello, prescrita en el numeral 11 del
}

ejecución de garantías, desde un aspecto meramente instrumental, mas no como un título ejecutivo sobre el cual se promueve ejecución.

Este razonamiento ha conllevado a preguntarnos: ¿Cuál es el título ejecutivo que permite la procedencia del proceso de ejecución de garantías reales? Atendiendo a que no existe una posición definida de la Corte Suprema de Justicia, nosotros nos adscribimos a esta última, pues estimamos que el título ejecutivo es de naturaleza compleja, estando conformado solamente por el documento que contiene la garantía real y el estado de cuenta de saldo deudor ${ }^{4}$. La razón radica en que la regulación desarrollada por el legislador infraconstitucional está destinada a que la obligación garantizada sea materia de acreditación, y que bien puede serlo mediante un título ejecutivo, pero no significa que esta va a poder ser ejercida como tal, sino que únicamente cumplirá una finalidad probatoria documental; conclusión que puede ser asimilada con una interpretación sistemática del numeral 1 y 2 del artículo 720 del Código Procesal Civil.

Retomando el análisis de los requisitos de procedencia, el numeral 2 del artículo 720 del Código Procesal Civil denota básicamente la propuesta formulada en el párrafo anterior, por lo que el ejecutante deberá anexar a su demanda el documento que contiene la garantía real y el estado de cuenta de saldo deudor. Debe tener en consideración, además, el precedente vinculante constituido en el Sexto Pleno Casatorio, dado que difiere la exigencia normativa en cuanto a la calidad del ejecutante, esto es, en la medida que sea ajeno o pertenezca al sistema financiero.

Los numerales 3 y 4 del artículo 720 de la norma adjetiva citada versa sobre la tasación comercial de bienes muebles e inmuebles, documento suscrito por profesionales (ingenieros, arquitectos) que debe estar actualizado a efectos de que, en la posterior ejecución forzada, no se le perjudique al ejecutado con una valorización menor al que correspondía realmente al momento de la venta. No es necesario presentar una tasación nueva si es que los justiciables, en la relación material, han decidido establecer un valor actualización del bien. Sin perjuicio de ello, el juez, de oficio o a pedido de parte, está facultado para ordenar una nueva tasación solo si es que aprecia que el valor pactado por

artículo 688 del Código Procesal Civil. Esta situación es distinta para las empresas del sistema financiero, pues el artículo 132 de la Ley 26702 regula lo siguiente: "En aplicación del artículo 87 de la Constitución Política, son formas mediante las cuales se procura, adicionalmente la atenuación de los riesgos para el ahorrista: (...) 7. El mérito ejecutivo de las liquidaciones de saldo deudores que emitan las empresas". 
las partes no está actualizado, conforme al artículo 729 del citado Código.

Finalmente, el numeral 5 del artículo 720 del Código Procesal Civil prescribe la carga del ejecutante de presentar certificado de gravamen. En este se apreciarán las afectaciones al bien materia de remate, mas no la historia o antecedentes del bien, razón por la cual se dificulta cumplir a cabalidad lo dispuesto en el artículo 734 del Código citado, sobre todo la información concerniente al bien materia de remate. Sin embargo, sí podrá apreciarse con este documento si la garantía real se encuentra debidamente inscrita, aspecto esencial que justifica la necesidad de exigencia de este requisito. Además, podrá denotarse la existencia de terceros que tengan a su favor cargas o gravámenes sobre el bien materia de ejecución forzada, hecho que generará la aplicación del artículo 690 de la norma civil adjetiva, es decir, su notificación con el mandato de ejecución para que puedan hacer valer su derecho conforme corresponda.

El legislador ha establecido que, en los procesos de ejecución de garantías, el ejecutado puede cumplir con el pago de lo adeudado dentro de los tres días de notificado con el mandato de ejecución, o ejercer su derecho de defensa formulando contradicción, excepciones o defensa previa, de lo contrario se iniciará el procedimiento de remate del bien en garantía (artículos 721, 722 y 723 del Código en comentario). El plazo otorgado para estos casos discrepa del proceso de ejecución en general, pues en este se otorga el plazo de cinco días para las acciones antes reseñadas.

La última disposición especial a comentarse es la contenida en el artículo 724, recibiendo su última modificación con la Única Disposición Complementaria Modificatoria del Decreto Legislativo № 1231, publicado el veintiséis de septiembre del dos mil quince. Pues bien, dicho artículo primigeniamente no permitió que el ejecutante pueda tener una solución célere cuando el monto del gravamen sea menor a lo adeudado, dado que lo obligaba a iniciar un nuevo proceso ejecutivo para el cobro del saldo no cubierto. Luego, con el Decreto Legislativo N. 1069, publicado en el diario oficial "El Peruano" con fecha veintiocho de junio del dos mil ocho también se modificó este artículo, favoreciendo al ejecutante al establecer que el saldo deudor podía verse cubierto en el mismo proceso bajo las reglas de las obligaciones de dar suma de dinero. Por último, con el Decreto Legislativo N.o 1231, publicado en el diario oficial "El Peruano" el veintiséis de septiembre del dos mil quince, el ejecutante tiene dos opciones: proseguir con la ejecución del monto de saldo deudor en el mismo proceso con las reglas de las obligaciones de dar suma de dinero, o iniciar un nuevo proceso de ejecución para tal fin.

\subsection{La contradicción en el proceso de ejecución de garantías}

\subsubsection{Concepto y naturaleza jurídica}

De conformidad con el Diccionario de la lengua española, el vocablo "contradicción" es definido como una acción y efecto de contradecir, oposición (decir lo contrario o algo antagónico), o el derecho de una parte, en el contexto de un proceso judicial o procedimiento administrativo, a conocer escritos y pruebas de su contraparte, para formular sus alegatos y ofrecer otras pruebas. Puede ser incluido como un principioimplícito al derivar de la tutela judicial efectiva, fundamentándose en la necesidad de un previo conocimiento oportuno de la contraparte de los actos que se configuran en un proceso o procedimiento, y así poder ejercer adecuadamente su defensa.

El término contradicción, en materia del proceso civil peruano, es ambivalente. Encontramos, por un lado, que los artículos 2 y 3 de la norma adjetiva civil prescriben expresamente al derecho de contradicción del emplazado como una expresión del derecho a la tutela jurisdiccional efectiva, comúnmente entendida como la contestación de demanda regulada en el artículo 442 del Código Procesal Civil. Es decir, de inicio solo es una locución asimilada al ejercicio del derecho de defensa en un proceso de carácter declarativo.

Sin embargo, como expone la reconocida procesalista Ariano (2017), la contradicción en el marco de un proceso de ejecución tiene una connotación distinta, pues no se dirige a negar o desmentir una demanda en un proceso declarativo, sino que versa sobre un acto perteneciente exclusivamente al ejecutado que generará una incidencia declarativa y sumaria en el mismo proceso, suspendiendo la ejecución hasta que haya pronunciamiento judicial que ampare o desestime su formulación, ya sea total o parcialmente.

Bajo esa premisa, resulta discutible considerar que el vocablo "contradicción" sea el más adecuado para referirnos a la defensa que ejerce el ejecutado en un proceso de ejecución, dado que es posible la confusión terminológica e inclusive conllevaría a generar errores en el juzgador, quien puede considerar erradamente que se está en un proceso ordinario donde la resolución final sea la sentencia, esto es, declarando fundada o infundada la demanda presentada por el ejecutante. Por tal motivo, Franciskovic (2017) sugiere que se reemplace dicho vocablo por el de "oposición", siendo este último una expresión del derecho de contradicción, en el que se pueda entender de forma más apropiada la 
defensa del ejecutado consistente en los supuestos del tercer párrafo del artículo 690-D del Código Procesal Civil.

\subsubsection{Causales de contradicción}

Como se había expuesto, la contradicción forma parte de la estructura del proceso de ejecución como una incidencia. Sin embargo, atendiendo a su naturaleza sumaria, el legislador infraconstitucional no solo estableció limitaciones al ofrecimiento probatorio, sino también elaboró una enumeración cerrada de causales para contradecir. Consecuentemente, atendiendo a que la norma procesal contenida en el artículo 690-D es de carácter imperativo 5, aparentemente no correspondería integrar-vía interpretación extensivacausales no contempladas en su redacción actual. Los supuestos alegables en la contradicción son:

"Artículo 690-D.- Contradicción: (...) La contradicción solo podrá fundarse según la naturaleza del título en: 1 . Inexigibilidad o iliquidez de la obligación contenida en el título; 2 . Nulidad formal o falsedad del título; o, cuando siendo este un título valor emitido en forma incompleta, hubiere sido completado en forma contraria a los acuerdos adoptados, debiendo en este caso observarse la ley de la materia; 3 . La extinción de la obligación exigida".

Evidentemente, el juez debe evaluar cada situación en concreto y definir si los argumentos del ejecutado se subsumen en los supuestos detallados, pues no basta solo la literalidad del posible supuesto que de parte se enuncie en la contradicción, sino que de su contenido o fundamentación se evidencie ello. De no ser positivo este control, lo que corresponderá es la declaración liminar de improcedencia de la contradicción, conforme a la parte última del artículo en comentario.

En relación al trámite procesal, la contradicción en el proceso de ejecución de garantías reales se interpone dentro de tres días de notificado el ejecutado con el mandato de ejecución. Luego, se corre traslado a la parte ejecutante quien puede absolver y ofrecer medios probatorios, desencadenando la emisión de un auto final que se pronunciará sobre esta incidencia cognitiva sumaria. Por otro lado, si no se formula contradicción, solo le corresponderá al juzgador competente expedir un auto que ordene llevar adelante la ejecución (artículo 690-E del Código Procesal Civil).

La primera causal regulada en el artículo 690-D del Código Procesal Civil (inexigibilidad o iliquidez de la

${ }^{5}$ Artículo IX del Título Preliminar del Código Procesal Civil: "Principios de Vinculación y de Formalidad.- Las normas procesales contenidas en este Código son de carácter imperativo, salvo regulación permisiva en contrario. Las formalidades previstas en obligación) es un supuesto de contradicción por motivos sustanciales utilizados por los ejecutados en el marco de un proceso único de ejecución. Como manifiesta Sevilla (2017), "entendemos que el medio de ataque a la ejecución cuestiona la obligación contenida en el título ejecutivo; es decir, cuestiona al acto contenido en aquel y no al documento que lo contiene" (p. 55). Se dirige a cuestionar la ejecutabilidad deltítulo por carecer de una prestación cierta, expresa y exigible. Resulta ser cierta cuando la prestación esté señalada en el título, expresa cuando figura allí mismo y no es materia de interpretación o presunción, y exigible en tanto la modalidad (condición, plazo o modo) sujeta a la prestación se ha cumplido. La obligación es ilíquida cuando su monto no se encuentre determinado; es liquidable mediante una simple operación aritmética, por lo que la previa liquidación configura la cuantía de la obligación cuyo pago se pretende.

Siendo así, en principio no solamente es inexigible una obligación cuando es modal, es decir, cuando está sujeta a condición (suspensiva o resolutoria), plazo o cargo; también lo es cuando se trata de "una obligación prescrita y que dicha prescripción ha sido declarada judicialmente-ya sea en vía de proceso autónomo o en vía de excepción-, deviniendo dicha obligación en inexigible ya que la posibilidad de solicitar su cumplimiento judicialmente se ha extinguido" (Sevilla, 2017, p. 56). Dicho esto, cabe hacer la distinción con la causal de extinción de la obligación, pues esta última indica la disolución de una relación jurídica, enmarcada por los supuestos de pago, novación, compensación, condonación y consolidación regulados en el Código Civil.

Hurtado (2017) indicaba que en el proceso de ejecución solo se puede demandar obligaciones exigibles, esto es, cuando se haya vencido el plazo para cumplirla, cuando se convenga una condición y no se cumpla, o cuando se haya formulado un cargo; añade que la obligación es exigible aun cuando se interpone demanda ante un juez incompetente por razón del territorio, dado que es prorrogable $y$, en todo caso, le corresponde a la contraparte, vía excepción, cuestionar la competencia, pero que no desvirtúa la exigibilidad de la obligación.

En cuanto a la segunda causal, está referida al documento (mas no al acto) que no cumple con la forma prescrita por la ley. Por ejemplo, se da en los casos en que un título valor no cuente con los requisitos esenciales, cuando el documento constitutivo de la garantía no cumple con la forma prescrita por Ley para

este Código son imperativas. Sin embargo, el Juez adecuará su exigencia al logro de los fines del proceso. Cuando no se señale una formalidad específica para la realización de un acto procesal, éste se reputará válido cualquiera sea la empleada". 
generar efectos, o también si el título valor emitido por una persona jurídica solo es suscrito por uno de los dos representantes (cuando el poder consignaba que ambos debían emitir títulos conjuntamente).

La falsedad implica situaciones anómalas relacionadas a la falta de declaración de voluntad del obligado o a la alteración del contenido del documento, teniéndose como ejemplo común la firma falsificada del obligado y consignada en un título. Seguidamente, el título valor incompleto llenado de forma contraria a los acuerdos pactados es un supuesto acorde a la Ley de Títulos Valores, Ley N.o 27287, en sus artículos 10 y 19, correspondiendo la carga de la prueba de los acuerdos transgredidos al ejecutado, quien debe adecuar su ofrecimiento probatorio solamente a documentos; por ejemplo, cuando se aplica una tasa de interés diferente a la empleada en el contrato, siendo un cuestionamiento que también se hace extensivo a la liquidación efectuada por la ejecutante.

Finalmente, la tercera causal (extinción de la obligación) implica que el vínculo obligatorio se ha disuelto porque el deudor ha cumplido con su prestación debida, o también por otros supuestos establecidos en el Código Civil, que son: dación en pago, condonación, novación, compensación, transacción, mutuo disenso, consolidación. En el mismo sentido se pronuncia Cárdenas (2018), al referir que los hechos extintivos para la invocación de la presente causal no tienen discrepancia con las reguladas para las obligaciones del derecho común.

\section{EL EJERCICIO ABUSIVO DE DERECHO EN EL PROCESO DE EJECUCIÓN DE GARANTÍAS}

\section{1. ¿Por qué y para qué ocurre?}

Para resolver las preguntas, se requiere hacer las siguientes precisiones en torno a los derechos, intereses y necesidades. Hablar de derechos nos remite necesariamente a hablar de intereses. En el marco del Derecho, el mercado juega un papel imprescindible, pues en este escenario se desarrollan los innumerables intercambios económicos de la sociedad. Estos responden, básicamente, a necesidades e intereses. Escobar (1998) mencionaba que, antes de precisar el concepto de interés, se debe explicar qué significa la necesidad; define a esta última como aquella exigencia de la vida humana, denotando un actual estado de insatisfacción del cual la persona proyecta salir.

Con ello, el mencionado autor refiere que el interés es una situación de tensión entre la persona y el bien idóneo para la satisfacción de sus necesidades. No debe interpretarse a este estado como uno estático, sino el requerimiento, como presupuesto, de una valoración o determinación por parte de la persona, con la finalidad de convencerse que con un bien específico va a satisfacer su necesidad. Dicho esto, es válido señalar: cuando se transgreden derechos, implícitamente también se transgreden intereses. Es así porque estos no solo son presupuestos de aquellos, sino también adquieren relevancia jurídica a partir de su reconocimiento en el ordenamiento jurídico, y que finalmente dan lugar a los derechos subjetivos. De esa manera, ante su trascendencia jurídica, en el escenario de una transacción económica, es probable su afectación a través de las actuaciones de los sujetos intervinientes.

La parte ejecutante, mayormente ubicada en la casuística como una entidad bancaria, tiene como interés el bien dinerario al que se encuentra obligado el ejecutado a entregar a su favor. La búsqueda del cumplimiento de la prestación por parte del deudor tiene un marco legal o regular; la irregularidad se presentaría cuando se busca el cumplimiento de la prestación de una manera agresiva, superando los límites del derecho de crédito y lesionando los cimientos del orden jurídico. El ejercicio abusivo de derecho del ejecutante, en el marco de un proceso de ejecución de garantías, tendría como motivo el cumplimiento célere de la obligación de dar, sin importar los agravios injustificados a los derechos e intereses de la parte ejecutada, con la finalidad de satisfacer su necesidad consistente en tener un índice positivo de liquidez, y así cumplir otras obligaciones. Evidentemente, este actuar violatorio de la buena fe se traduce en un interés no tutelado por el ordenamiento jurídico.

A propósito de lo mencionado, para referirnos al ejercicio abusivo se requiere, como presupuesto, la existencia de un derecho subjetivo que es empleado fuera de los límites trazados por el ordenamiento jurídico; de allí que derive en un acto ilícito. Es complejo esbozar una definición de derecho subjetivo en razón de las múltiples situaciones que comprende, aunque lo más común sea relacionarlo con facultades, poderes y deberes. Zatti (2005) sostenía que el derecho subjetivo implica la posición del sujeto frente a una norma jurídica que le permite satisfacer sus intereses (económicos o morales).

Lo cierto es que, como expresa Morales (2008), el derecho subjetivo es una situación jurídica subjetiva de ventaja activa, que implica la atribución de un poder específico (o permiso normativo especial) para tutelar el interés propio. Este derecho contiene facultades que el ordenamiento jurídico atribuye, pero que de ningún modo implica su realización ilimitada. De esa manera, el ejercicio del derecho subjetivo debe cumplir con ciertos 
parámetros que, de excederse, implicaría asumir al acto como configurativo de un abuso. Si bien se detallará más adelante, es ilustrativo considerar al derecho subjetivo a contratar, que no es otro que la libertad de contratación, por el que no solo se elige con quién contratar, sino también se fija la reglamentación contractual (libertad contractual), de tal manera que el ejercicio abusivo de dicho derecho podría devenir en la constitución de cláusulas abusivas. Además, considerando la dirección del presente trabajo, es válido sostener que, al ser la acción un "derecho subjetivo inspirado en el deber del Estado de otorgar tutela jurídica" (Gozaíni, 1995, p. 664), este derecho también pueda ser ejercido abusivamente, a través de demandas o actuaciones procesales que no tengan asidero o sean contrarias a la buena fe. Tales situaciones no cuentan con el permiso "específico" del ordenamiento jurídico debido a su abusividad, y es por ello que se extraen del contexto de un derecho subjetivo, trasladándose al campo de la ilicitud.

\section{2. ¿Cuáles son los perjuicios generados a la parte ejecutada?}

\subsubsection{El debido proceso}

El Estado tiene el deber de generar mecanismos adecuados para la solución de conflictos intersubjetivos de intereses con relevancia jurídica, para efectos de tutelar al ciudadano y mantener la paz social en justicia. Por tanto, más allá de las críticas que pueda recibir nuestro alicaído servicio de justicia, el legislador nacional ha optado por reconocer como principio del proceso civil (que incluye al proceso de ejecución de garantías), a la tutela jurisdiccional efectiva, siendo un derecho constitucional de los justiciables. Con el artículo I del Título Preliminar del Código Procesal Civil, se prescribe que a toda persona se le atribuye el derecho a la tutela jurisdiccional efectiva, con la finalidad de ejercer o defender de sus derechos o intereses, sometiéndose a un debido proceso.

Este principio de carácter procesal tiene su reconocimiento en el artículo 139 numeral 3 de la Constitución peruana, estableciéndose que la función jurisdiccional debe observar el debido proceso y la tutela jurisdiccional. Aproximándonos a un alcance de la jurisdicción, es aquella potestad que el Estado confiere a ciertas entidades (en este caso, los órganos del Poder Judicial) para constituir o declarar un derecho, o en general, resolver una cuestión controvertida de trascendencia jurídica, siendo las decisiones de característica irrevisable porque adquieren calidad de cosa juzgada. El límite de la jurisdicción está referida a la competencia, por razón de territorio, especialidad o materia, grado, etc.

Con lo expuesto, se colige que el desarrollo de ese poder por parte de los magistrados del Poder Judicial necesariamente considerará a la tutela jurisdiccional y el debido proceso, por mandato constitucional. Sin embargo, ocurre que se ha pretendido diferenciar conceptualmente a estos derechos-principios, indicando el Tribunal Constitucional, por ejemplo, que la tutela jurisdiccional sería el derecho de acceder a los órganos jurisdiccionales, así como asegurar el cumplimiento de la decisión final; y por otro lado, el debido proceso sería la observancia de reglas dentro del proceso judicial para proteger derechos subjetivos ${ }^{6}$.

Indistintamente de las posiciones sobre el debido proceso y la tutela jurisdiccional efectiva, ambos constituyen principios de naturaleza adjetiva, de aplicación imperativa y siempre orientada a la solución de conflictos de intereses. Con la evolución del entendimiento del proceso civil, el contenido infranqueable de los mencionados principios ha sufrido una dinámica de elasticidad o flexibilización, arribándose en la experiencia peruana, por ejemplo, que las pretensiones sobre derecho de familia deban ser tramitadas en un procedimiento adecuado para afrontar el problema humano.

Esta experiencia, en el ámbito del proceso ejecutivo, precisamente el de garantías reales, no ha sido replicada. De hecho, podría decirse que es el proceso más formalista del sistema procesal civil, pues tiene requisitos especiales, plazos perentorios o preclusorios que no admiten mayor discusión, limitaciones en la contradicción y ofrecimiento de la prueba, entre otras características que reafirman nuestra premisa. La razón del excesivo formalismo radica en la búsqueda de solución de la litis con la mayor celeridad posible, logrando un impacto positivo sobre la eficiencia económica. También tiene sustento en la aparente carencia de discusión sobre los derechos sustantivos, al exigirse judicialmente solo el cumplimiento de estos; pero, como ya habíamos mencionado anteriormente, no suscribimos tal idea porque sí hay cierta controversia en el proceso de ejecución de garantías, manifestada a través del ejercicio de la contradicción por parte del ejecutado y la subsecuente constitución de una incidencia cognitiva.

${ }^{6}$ Sentencia del Tribunal Constitucional en el expediente N.o 097272005-PHC/TC de fecha seis de octubre del dos mil seis. Fundamento 
jurídico número siete. 
La profusa formalidad del proceso de ejecución de garantías reales no admitiría discusión si aceptáramos aisladamente las razones antes expuestas. Sin embargo, se requiere ver más allá de simples sustentos económicos y legales, o de fundamentos superfluos, carentes de una acepción integral. Por tanto, corresponde que el debido proceso sea interiorizado como derecho humano (a su vez, como bien humano), cubriendo exigencias y necesidades propias de la naturaleza humana, con el propósito de alcanzar el respeto de la dignidad de la persona y su perfeccionamiento.

Sobre el ámbito formal del debido proceso, el Tribunal Constitucional ha sostenido que comprende una serie de derechos y ante su inobservancia, el proceso se vuelve irregular; además, las reglas deben garantizar un estándar de participación justa o debida en el trámite del procedimiento o proceso ${ }^{7}$.A diferencia de la dimensión sustancial, la cual implica que la decisión judicial debe cumplir con un estándar de justicia, conformada por la razonabilidad y proporcionalidad ${ }^{8}$. Entonces, se procurará con el aspecto material que el proceso resuelva un conflicto de intereses mediante una decisión digna, y por tanto, justa; mientras tanto, surge la posibilidad del cumplimiento de formas de los actos procesales, sin que se obtenga una decisión justa. Nosotros formulamos la posibilidad de vulneración de este derecho en el proceso de ejecución de garantías. Se vulnera en la medida que es ejercido abusivamente por el ejecutante (debido proceso formal), y trasladándose esta afectación al ejecutado, se incumple con el estándar de justicia que debería contener toda resolución judicial. Desde luego, implica resolver una controversia amparando el interés de una de las partes, en detrimento del otro, sin que exista una fundamentación con base en la justicia y la paz social.

\subsubsection{Consecuencias patrimoniales y extrapatrimoniales}

Como en todo proceso judicial, el litigante asume un costo que puede ser o no ser razonable, justo o injusto. Así, por ejemplo, se tienen a los gastos que asume por la activación y funcionamiento del aparato jurisdiccional (costas procesales), y los gastos relacionados con la contratación de un profesional del derecho para la

\footnotetext{
7 Sentencia del Tribunal Constitucional en el expediente N.우 005792013-PA/TC, de fecha veinticuatro de octubre del dos mil catorce, fundamento jurídico número 5.3.1

8 Sentencia del Tribunal Constitucional en el expediente N.ㅇ 97272005-PA/TC, de fecha seis de octubre del dos mil seis, fundamento jurídico número 7.

${ }^{9}$ Artículo 923 del Código Civil.- "La propiedad es el poder jurídico que permite usar, disfrutar, disponer y reivindicar un bien. Debe
}

asistencia o asesoría técnica en el proceso judicial instaurado (costos procesales). Empero, la parte ejecutada también obtiene otras consecuencias, de carácter patrimonial o no patrimonial.

Nos referimos, en el aspecto patrimonial, a la posible vulneración del derecho de propiedad del ejecutado. La propiedad es el más importante de los derechos reales, recogiendo los siguientes poderes económicos que una persona puede ejercer respecto de un bien, según el Código Civil': usar, disfrutar, disponer y reivindicar. Es aplicable, en el ámbito privado, el precepto normativo constitucional consistente en la posibilidad de la persona de hacer lo no prohibido ${ }^{10}$, aplicándose al propietario, que puede ejercer el derecho de propiedad respecto del bien según le parezca, salvo la existencia de norma prohibitiva de cierta conducta. Se expresa en los cuatro poderes señalados, dado que el propietario goza del bien (usar), saca provecho de él (disfrutar), recupera el bien cuando sea despojado o puede defenderse de agresiones por parte de terceros (reivindicar), y está facultado para transferir el derecho total o parcialmente a terceros (disponer), aunque también puede no hacer nada sobre el bien, siendo el acto omitivo una decisión del propietario que forma parte de sus atributos.

No versa sobre un derecho absoluto, pues existen normas regulatorias que generan restricciones al ejercicio del dominio, además de la observancia al bien común. A pesar de ello, se trata de un instrumento destinado a alcanzar el desarrollo económico y bienestar, aunque también puede ser un medio de destrucción de la vida social (Mejorada, 2004). Esto último es lo controvertido frente al proceso judicial de ejecución de garantías reales, toda vez que es probable la pérdida de la titularidad del derecho de propiedad del bien en caso se declare infundada la contradicción al mandato ejecutivo, o en su defecto, no se interponga contradicción, conllevando a la ejecución forzada de los bienes otorgados en garantía de un mutuo.

Entonces, como consecuencia de afrontar el proceso judicial de ejecución de garantías, la parte ejecutada, sea una persona natural o jurídica, se encuentra en riesgo de perder su propiedad, traduciéndose en una consecuencia patrimonial de carácter negativo en su esfera personal. En caso la decisión judicial fuese

ejercerse en armonía con el interés social y dentro de los límites de la Ley".

${ }^{10}$ Artículo 2, inciso 24, literal b de la Constitución peruana: "Toda persona tiene derecho: (...) 24. A la libertad y a la seguridad personales. En consecuencia: a. Nadie está obligado a hacer lo que la ley no manda, ni impedido de hacer lo que ella no prohíbe". 
injusta, esta tendría una implicancia trascendental en la sociedad, pues al ser la propiedad un elemento fundamental para el desarrollo y generación de recursos, su pérdida significaría la carencia de protección a la inversión privada y, consecuentemente, ausencia de garantía del ejercicio de la libertad económica conforme a los intereses de las personas.

Por otro lado, sobrellevar un proceso judicial de garantías reales también tiene consecuencias extrapatrimoniales. Por el hecho de ser personas, tenemos atributos espirituales que no se ubican en un espacio físico determinado; a diferencia de los bienes materiales. De esa manera, se advierte un menoscabo moral en el justiciable, toda vez que afrontar una decisión contraria a sus intereses le puede causar detrimentos contra su integridad, salud mental y psicológica. Es una consecuencia común, frente a un proceso judicial, el grado de incertidumbre del litigante sobre los resultados de la controversia, posibilitándose un cuadro de estrés, ansiedad o, incluso, depresión. Pero, asumir la pérdida del bien de su propiedad que garantiza la deuda, indudablemente generará una aflicción o malestar psicológico de mayor intensidad.

\section{3. ¿Cómo se configura el ejercicio abusivo de derecho?}

\subsubsection{A partir de la relación sustantiva}

Loutayf (2015) menciona que la Corte Suprema de Justicia de la Nación de Argentina, en el caso "Burman", permitió la discusión del abuso de derecho en un proceso de ejecución hipotecaria de un bien que era la vivienda familiar, sustentado en hechos notorios (variaciones en la política económica), teoría de la imprevisión y ejercicio regular de derechos. Para estos casos, ante una emergencia económica que imponga una desigualdad en el valor de las prestaciones en un contrato de ejecución continuada o periódica (por ejemplo, el contrato de mutuo), se está ante un evento imprevisible que atañe al hecho generador de la relación jurídica sustantiva. Por lo tanto, cualquier ejercicio de derecho que pretenda aprovecharse de esta situación perjudicial, podría considerarse abusivo al vulnerarse la buena fe.

La jurisprudencia citada permite recordar la relativización del principio pacta sunt servanda, dando

\footnotetext{
${ }^{11}$ Artículo 1440 del Código Civil.- "En los contratos conmutativos de ejecución continuada, periódica o diferida, si la prestación llega a ser excesivamente onerosa por acontecimientos extraordinarios e imprevisibles, la parte perjudicada puede solicitar al juez que la reduzca o que aumente la contraprestación, a fin de que cese la excesiva onerosidad. Si ello no fuera posible por la naturaleza de la prestación, por las circunstancias o si lo solicitara el demandado, el juez decidirá la resolución del contrato. La resolución no se extiende a las prestaciones ejecutadas".
}

lugar a la cláusula rebus sic stantibus, mediante la cual se "estipula que las obligaciones contractuales pactadas deben ser cumplidas estrictamente, con la condición de que se mantuviera el contrato como se pactó originalmente" (Ruiz, 2006, p. 155). En ese escenario, toda causa sobreviniente e imprevisible que modifique la base del contrato amerita su revisión y reformulación en aras del equilibrio entre las partes. Para tal fin, la teoría de la imprevisión, en nuestro sistema jurídico, está contemplada en el artículo 1440 del Código Civil ${ }^{11}$, habilitándose a la parte perjudicada para que pueda solicitar al órgano jurisdiccional una especie de reestructuración del negocio jurídico, pues implicará la reducción o aumento de la contraprestación. En caso no sea posible esta mutabilidad, se optará por la resolución del contrato. Atendiendo a lo señalado, no consideramos que la reducción o aumento de la contraprestación y la resolución de contrato sean puntos que puedan discutirse en un proceso de ejecución de garantías; sin embargo, sí es posible que el juez aprecie los hechos imprevisibles y extraordinarios para efectos de emitir una decisión arreglada a derecho y justicia.

Otra cuestión importante que se viene suscitando en estos tiempos, es la relacionada a los desahucios en España ${ }^{12}$. El primer antecedente lo encontramos en el año 2013, cuando el caso de un obrero de origen marroquí, expulsado de su vivienda en Barcelona, originó el pronunciamiento del Tribunal de Justicia de la Unión Europea, declarando que las cláusulas de vencimiento anticipado eran contrarias al derecho comunitario. De esa manera, en España se modificó el artículo 693.2 de la Ley de Enjuiciamiento Civil, a través de la Ley $1 / 2013$, constituyendo un cambio sustancial porque, para activar la cláusula de vencimiento anticipado, se requerían tres cuotas impagadas, mas no una, como originariamente se había planteado (Gil, 2018). Sin embargo, esta norma no es aplicable retroactivamente, subsistiendo las cláusulas anteriores a la fecha de su entrada en vigor (15 de mayo del 2013). Surge la duda sobre si es posible considerar a la cláusula abusiva dentro del campo del ejercicio abusivo de derecho. En torno al fundamento de la cláusula vejatoria o abusiva ${ }^{13}$, se han generado dos posiciones: la primera asume a la cláusula abusiva dentro de la

\footnotetext{
12 Para mayor entendimiento, el desahucio es el acto con el que se despoja a una persona la posesión de un bien, en razón de un proceso de ejecución hipotecaria. También se le denomina lanzamiento.

13 El primer párrafo del artículo 46 de la resolución SBS N.o 17652005, define a las cláusulas abusivas como "todas aquellas estipulaciones no negociadas que en contra de las exigencias de la buena fe causen, en perjuicio de los usuarios, un desequilibrio importante de los derechos y obligaciones de las partes que se
} 
teoría del abuso del derecho, pues la imposición de la parte fuerte frente a la parte débil para alterar el equilibrio jurídico del contrato constituye el ejercicio abusivo de la libertad contractual, y la segunda posición la encuadra en el principio de buena fe, exigiéndose que los contratantes actúen con honestidad, diligencia, lealtad, probidad y responsabilidad en todas las etapas del iter contractual (Posada, 2015).

En ambos casos, es posible contrastar el deber de las partes de actuar de manera correcta durante la vigencia de la relación sustantiva, evitando el beneficio indebido de uno a costa del perjuicio del otro, y proscribiendo el ejercicio abusivo de los derechos adquiridos a partir del perfeccionamiento del contrato. Al respecto, Arango (2016) sostiene que "cualquiera puede ser la causa del desequilibrio o conflicto: el abuso del derecho a contratar, la violencia, la inaplicación de una actitud recta y honrada, etc., pero solo una es causa de existencia de una cláusula abusiva" (p. 249). Sin que exista esta causa, puede predicarse un conflicto en la relación intersubjetiva, pero no una cláusula abusiva. Por eso, es importante el principio de la buena fe como determinador de las conductas transgresoras de los intereses individuales de las partes, y en tanto impone a la parte fuerte respetar la confianza otorgada por la parte débil respecto a un contenido justo del contrato celebrado.

Retomando el asunto de la problemática social en España a causa de los lanzamientos (ejecución de hipoteca) por cláusulas abusivas, el 26 de marzo del 2019 el Tribunal de Justicia de la Unión Europea dio respuesta a las cuestiones planteadas por el Tribunal Supremo de España y el juzgado de Primera Instancia número 1 de Barcelona a raíz de los litigios iniciados por Abanca Corporación Bancaria y Bankia contra sus clientes ${ }^{14}$, partes vinculadas por la celebración de préstamos con garantía hipotecaria. La sentencia del TJUE aprueba que el juez utilice como remedio, frente a una cláusula abusiva de vencimiento anticipado, su sustitución por una prerrogativa de la legislación nacional, siempre que el contrato de préstamo hipotecario no pueda subsistir por la eliminación de la cláusula abusiva y la anulación íntegra del contrato sea perjudicial para el consumidor.

El Tribunal de Luxemburgo avala este criterio porque, de obligarse al juez a anular el contrato en su totalidad,

deriven del contrato. Se considera que una cláusula no se ha negociado cuando haya sido redactada previamente y el usuario no haya podido influir en su contenido".

14 En el caso de Abanca Corporación Bancaria, esta entidad desembolsó la suma ascendente a 100.000 euros a favor de su cliente (fijándose como plazo de devolución 30 años), pero el juez español determinó que era abusiva la cláusula que permitía el el efecto inmediato es hacer exigible el saldo pendiente de devolución, siendo un monto que, eventualmente, excedería la capacidad económica del deudor. Además, no constituiría una medida disuasoria, ya que la exigibilidad inmediata de lo adeudado perjudica más al consumidor que al prestamista. Sin embargo, la decisión del Tribunal, más que la sustitución de la cláusula abusiva, en la práctica, ha generado el archivamiento de las ejecuciones hipotecarias. Así, Missé (2019) informó para el diario "El País" un caso en particular:

Un juzgado de Mollet de Vallés (Barcelona) valoró que "no procede la continuación del procedimiento aplicándose supletoriamente norma de derecho nacional, habiendo ratificado su petición el consumidor de que se archive". El juez consideró que el impago de ocho cuotas "es nimio", pues sólo se había producido el incumplimiento del 1,54\% del préstamo adeudado, por lo que estimó que la cláusula de vencimiento anticipado se "ha ejercitado de forma abusiva" y sobreseyó la causa.

Ante este escenario problemático, y en la espera del pronunciamiento del Tribunal de Justicia de la Unión Europea, el legislador español emite la Ley 5/2019, Ley reguladora de los contratos de crédito inmobiliario, con entrada en vigor el dieciséis de junio del dos mil diecinueve, estableciendo la ampliación del plazo de tres a doce meses de incumplimiento en la primera mitad de vida del préstamo (o no pagarse el 3\% del capital), y quince meses incumplidos en la segunda mitad (o no pagarse el 7\% del capital) para permitirse el proceso de ejecución. Así, en la vía legal y jurisprudencial española se ha intentado frenar esta incidencia presentada en la relación material, protegiéndose a los consumidores frente al abuso del prestamista o ejecutante.

\subsubsection{A partir de la relación procesal}

Desde el marco del proceso de ejecución de garantías, el ejercicio abusivo de derecho asume otra connotación. Ya no es un abuso de derecho sustantivo, sino que se materializa en un abuso procesal, y esto es válido porque el tema no es exclusivo del derecho civil (específicamente, responsabilidad civil), sino que, al pertenecer a la Teoría General del Derecho, resulta aplicable a cualquier rama del ordenamiento jurídico,

vencimiento anticipado del contrato y la exigencia de toda la deuda pendiente (incluyendo gastos e intereses) por el solo incumplimiento de una cuota. En cambio, en el proceso iniciado por Bankia tras el impago de 36 cuotas de un préstamo fijado a 37 años para la devolución, el juez declaró abusiva la cláusula de vencimiento anticipado que permitía a la entidad bancaria dar por vencido el préstamo si no se pagaba una, varias o todas las cuotas. 
derivando aspectos especiales según la rama a la que se haga referencia.

El abuso procesal es, en buena cuenta, toda conducta proveniente de las partes, el Juez y los auxiliares jurisdiccionales que lesiona la buena fe procesal, los deberes de lealtad y probidad en el ejercicio de las potestades, facultades, deberes y poderes de naturaleza procesal otorgados por el ordenamiento jurídico.

La conducta de las partes en el proceso constituye un tema cardinal para su buen desarrollo. La forma en la que los sujetos allí involucrados ejerciten sus derechos, deberes y poderes (conducta) debe orientarse conforme la finalidad que a cada uno de ellos el ordenamiento les ha reconocido y otorgado. Cuando el ejercicio del derecho, deber o poder se extralimita de ese marco, se configura un abuso. (Trigiani, 2017, pp. 34)

En el Código Procesal Civil peruano, específicamente el artículo IV del Título Preliminar ${ }^{15}$, establece cómo debe ser la conducta de las personas intervinientes en un proceso judicial, y en caso no se cumpla con ello, el Juez está en la obligación de impedir y sancionar cualquier conducta ilícita o dilatoria; también es recogido en el artículo 8 del TUO de la Ley Orgánica del Poder Judicial $^{16}$. Se trata de un mandato general, aplicable a todo tipo de proceso (la norma no incluye excepciones), con un contenido claro, pero con sanciones que pueden variar en uno u otro caso, aspecto que será de apreciación por el juzgador. La labor judicial, ante estas situaciones, es la de declarar lo que es justo, y lo que no lo es, a partir de la valoración de los hechos y las pretensiones de las partes, siendo el proceso la instancia idónea para identificar conductas abusivas.

Determinar si una conducta se erige como trasgresora y abusiva del derecho es una labor propiamente jurídica, pues tiene lugar en el marco de un juicio, aspecto esencial de esta rama del conocimiento, y no encuentra razón de ser en la simple ley, que pertenecería a lo político. Fue cuando la ley, en tanto norma general y abstracta, resultó insuficiente para dar eficacia y razón al actuar del sujeto que fue preciso adentrarse en el ámbito que resulta propiamente jurídico, esto es, en el juicio. (Miranda, 2016, p. 38).

Lógicamente, la conducta procesal se adecúa a deberes (lealtad, veracidad, buena fe) para conseguir el descubrimiento de la verdad sobre un determinado conflicto. El aparato jurisdiccional no debe ponerse en

${ }^{15}$ Artículo IV del Título Preliminar del Código Procesal Civil.- "Las partes, sus representantes, sus abogados y, en general, todos los partícipes en el proceso, adecúan su conducta a los deberes de veracidad, probidad, lealtad y buena $\mathrm{fe}^{\prime \prime}$. funcionamiento para solicitudes no conformes al ordenamiento jurídico, o lesivos al orden público y fines del proceso. Ante un contexto de antítesis de la moralización procesal (daño al proceso e injusticia) se requiere colocar en un segundo plano el principio dispositivo, con la finalidad de reforzar la idea de socialización y moralización al proceso, permitiendo adoptar las medidas correctivas en aras de una recta administración de justicia (Artavia \& Picado, 2016).

En doctrina se han propuesto dos modalidades de abuso procesal: abuso con el proceso y abuso dentro del proceso. De forma resumida, el primero está referido, por ejemplo, al ejercicio abusivo del derecho de accionar. En cambio, el segundo consiste en un proceso iniciado válidamente, pero en su desarrollo se presentaron conductas abusivas. Interesa más que todo precisar la modalidad de abuso con el proceso, en tanto no solo comprende al ejercicio del derecho de acción, sino también, y de forma general, al derecho de acceso a la justicia o tutela jurisdiccional efectiva. Los mencionados derechos de incidencia procesal, al ser ejercidos de forma abusiva sin importar que haya mediado dolo o culpa, y ocasionando un daño, generan una consecuencia negativa que debe ser sancionada oportunamente.

Este tipo de abuso recaído en el sujeto activo (accionante), impide un resultado favorable para su interés ilegítimo. Artavia \& Picado (2016) sostienen que, "sin caer en una casuística excesiva, podemos identificar como modalidades de abuso con el proceso a las demandas improponibles o proceso crasamente infundado, las demandas innecesarias, el proceso desviado, el fraude procesal y la estafa procesal" (p. 2). Los ejemplos citados denotan que el proceso es usado como un mecanismo para fines contrarios a la justicia, lealtad, buena fe, probidad y veracidad. En la opinión de Picó (2003), el abuso del derecho a litigar debe reducirse a su mínima expresión e identificarse excepcionalmente en el proceso, para no limitar de manera amplia el derecho a la tutela judicial efectiva.

En uno y otro caso, la imposición de medidas que neutralicen el ejercicio abusivo de derecho procesal exige que el Juez determine el cumplimiento de los presupuestos para su configuración, como son: a) conducta permitida por el ordenamiento jurídico; b) ejercicio contrario a los fines de la norma, o a la buena

${ }^{16}$ Artículo 8 del TUO de la Ley Orgánica del Poder Judicial.- "Todos los que intervienen en un proceso judicial tienen el deber de comportarse con lealtad, probidad, veracidad y buena fe. Los Magistrados deben sancionar toda contravención a estos deberes procesales, así como la mala fe y temeridad procesal". 
fe, moral y buenas costumbres; c) daño ocasionado a otro sujeto. Como explicábamos anteriormente, cuando hacemos referencia a la conducta, esta debe ser entendida como una acción u omisión que expresamente sea acorde a la norma jurídica. El segundo elemento debe ser apreciado de forma objetiva, sin perjuicio de que en el proceso correspondiente en el que se reclame resarcimiento por los daños irrogados se verifique la intencionalidad del agente. Finalmente, sobre el tercer elemento, Loutayf (2004) ha sostenido lo siguiente:

Con relación al daño, el que justifica la aplicación del principio de la proscripción del abuso no es sólo el de carácter patrimonial que pueda sufrir alguna o ambas partes, sino que basta el daño procesal, es decir, la demora y el alargamiento de trámites, lo que también constituye un daño para la Administración de Justicia por la mayor atención jurisdiccional y el desgaste que ello conlleva. (p. 7)

Chiovenda (1954) sostiene que la buena fe asume las formulaciones genéricas de los deberes procesales, y son las siguientes: a) obligación de no sostener una tesis desprovista de fundamento; b) obligación de no sostener a sabiendas hechos contrarios a la verdad; c) obligación de conducirse con lealtad y corrección frente al juez y la contraparte. Conductas como las descritas en el derecho italiano, según el autor, ayudarían a identificar la mala fe procesal. Este aspecto, en la actualidad y para el caso peruano, no ha variado ${ }^{17}$, y por el contrario se reconocen expresamente los deberes procesales; ahora, lo que corresponde determinar es la sanción por un acto abusivo.

Monroy (1996) refiere que la imposición de deberes en la conducta procesal es la expresión del derecho público

\footnotetext{
17 Básicamente, los supuestos mencionados son similares a los comprendidos en el texto normativo del artículo 112 del Código Procesal Civil, en tanto recoge las conductas temerarias o de mala fe de las partes, abogados y apoderados en el proceso.

18 "Artículo 52.- A fin de conservar una conducta procesal correspondiente a la importancia y respeto de la actividad judicial, los Jueces deben: 1 . Ordenar que se suprima la frase o palabra expresada o redactada en términos ofensivos o vejatorios; 2. Expulsar de las actuaciones a quienes alteren su desarrollo. Si se trata de una de las partes, se le impondrá además los apercibimientos que hubieran sido aplicables de no haber asistido a la actuación; y 3. Aplicar las sanciones disciplinarias que este Código y otras normas establezcan".

"Artículo 53.- En atención al fin promovido y buscado en el Artículo 52, el Juez puede: 1. Imponer multa compulsiva y progresiva destinada a que la parte o quien corresponda, cumpla sus mandatos con arreglo al contenido de su decisión. La multa es establecida discrecionalmente por el Juez dentro de los límites que fija este Código, pudiendo reajustarla o dejarla sin efecto si considera que la desobediencia ha tenido o tiene justificación; y 2. Disponer la detención hasta por veinticuatro horas de quien resiste sumandato
}

y la moralización del proceso, pues la sociedad tiene interés en la realización de un proceso civil correcto, expeditivo y adecuado. Como ya hemos precisado, el Título Preliminar del Código Procesal Civil recoge los principios de conducta procesal, y las medidas que puede adoptar el Juez para su cumplimiento se encuentran en el mismo cuerpo legal ${ }^{18}$, o inclusive en la Ley Orgánica del Poder Judicial ${ }^{19}$. Más allá de la totalidad de medidas coercitivas que puedan imponerse, consideramos que la sanción idónea frente a un ejercicio abusivo del derecho de accionar es la de desestimar la demanda (por infundada o improcedente), sin perjuicio de la imposición de multas, costas y costos, y dejando a salvo el derecho del perjudicado para accionar judicialmente ante la responsabilidad civil por el daño causado ${ }^{20}$.

Para el proceso de ejecución de garantías reales, somos de la opinión que también son aplicables estas medidas con la salvedad de analizar cada caso concreto, para efectos de imponer una sanción de manera proporcional al acto abusivo. A través de la contradicción, se pueden dar a conocer estas conductas, o en todo caso, el Juez en su calidad de director del proceso, también tiene el deber de adoptar decisiones que contrarresten los actos abusivos. Se cuestiona el deber de imparcialidad del juez si con el ejercicio de derecho de defensa no se alegan estos hechos; empero, concordamos con el criterio asumido por Picó (2012), por cuanto se requiere encontrar un relación de complementariedad entre el garantismo procesal y la eficacia de los derechos fundamentales que permita al Juez ejercer válidamente su facultad sancionadora, pues el "garantismo exacerbado puede originar la ineficacia del proceso, y la eficacia extrema puede propiciar la vulneración de las garantías básicas

sin justificación, produciendo agravio a la parte o a la majestad del servicio de justicia. En atención a la importancia y urgencia de su mandato, el Juez decidirá la aplicación sucesiva, individual o conjunta de las sanciones reguladas en este Artículo. Las sanciones se aplicarán sin perjuicio del cumplimiento del mandato".

19 Artículo 9 del TUO de la Ley Orgánica del Poder Judicial.- "Los Magistrados pueden llamar la atención, o sancionar con apercibimientos, multas, pedidos de suspensión o destitución, o solicitar su sanción, de todas las personas que se conduzcan de modo inapropiado, actúen de mala fe, planteen solicitudes dilatorias o maliciosas y en general, cuando falten a los deberes señalados en el artículo anterior, así como cuando incumplan sus mandatos. Esta facultad comprende también a los abogados".

20 Sanción similar a lo establecido por el artículo 4 del Código Procesal Civil: "Concluido un proceso por resolución que desestima la demanda, si el demandado considera que el ejercicio del derecho de acción fue irregular o arbitrario, puede demandar el resarcimiento por los daños y perjuicios que haya sufrido, sin perjuicio del pago por el litigante malicioso de las costas, costos y multas establecidos en el proceso terminado". 
de la actividad del juez - con su deber de imparcialidady de las partes -con sus derechos a la defensa-" (p. 280).

\subsubsection{Casuística nacional}

En la Casación N.o 2550-1999-La Libertad, publicada en el diario oficial "El Peruano" con fecha once de julio del dos mil, sobre un proceso de ejecución de garantías, la Corte Suprema indicó que si bien es cierto la Sala Superior había determinado que el inmueble materia de litis es de propiedad de la sociedad conyugal y ha sido gravado sin consentimiento del otro cónyuge, se trata de un argumento propio de una nulidad sustancial del título de ejecución, por lo que no debe ser tomado en cuenta para la contradicción. De esa manera, declara infundado el recurso de casación, no casa la resolución de vista que declaraba infundada la contradicción. Consideramos que la decisión se encuentra conforme a la norma procesal, específicamente el artículo 722 del Código Procesal Civil; sin embargo, se está permitiendo que mediante una resolución que adquiere calidad de cosa juzgada, se proceda a la ejecución forzada con el remate del bien otorgado en garantía, sin que esta haya sido constituida válidamente a sabiendas de la parte ejecutante. No nos parece que esto sea correcto desde el punto de vista de los fines del proceso.

En la Casación N.o 251-1998-Lima, de fecha veinticuatro de noviembre de mil novecientos noventa y ocho, se resolvió un litigio iniciado por Banco Continental contra Consorcio Papelero S.A. sobre obligación de dar suma de dinero (se toma en cuenta por tener reglas comunes al proceso de ejecución de garantías). En esta resolución, la Corte Suprema estableció que "las liquidaciones efectuadas por las empresas emanan de un acto unilateral y por tanto arbitrario, que no califican por sí solas como títulos ejecutivos, pues la ley y la doctrina reservan esa calidad a determinadas situaciones convencionales, en cuya formación siempre tiene intervención el obligado". Asimismo, indicó que solo tienen mérito ejecutivo en el proceso de ejecución de garantía real porque se presenta copulativamente con otros documentos requeridos en la Ley. Concuerdo en el hecho de que sí es posible que se generen abusos a partir de la liquidación, porque es el acreedor quien lo elabora unilateralmente, pero debería existir una causal de contradicción destinada a desvirtuarla. Tampoco es válido sostener que por ser elaborado unilateralmente esta necesariamente es arbitraria, o que ello sea razón suficiente para la pérdida de mérito ejecutivo. Así, por ejemplo, el artículo 688 del Código Procesal Civil regula que el documento impago de renta por arrendamiento es título ejecutivo, y este es elaborado por el arrendador unilateralmente; de igual forma, las liquidaciones para cobranza realizadas por las AFP's también tienen mérito ejecutivo, y no se les excluye por devenir de un acto unilateral. Por ello, es un craso error indicar que el mérito ejecutivo se reserva al documento en donde participe el acreedor y deudor.

En la Casación N.o 1969-1998-Sullana, publicada el veintiocho de diciembre de mil novecientos noventa y ocho, se resolvió un litigio iniciado por Banco Continental contra José Alejandro Rugel Pacherrez sobre ejecución de garantía hipotecaria. El cuestionamiento se centró en no haberse presentado una tasación actualizada del bien inmueble otorgado en garantía. La Corte Suprema indicó que no era necesario porque ya se había convenido el valor actualizado del bien; sin embargo, precisa que a la fecha de la demanda, habían transcurrido dos años y dos meses desde la tasación convencional, por lo que, pese a haberse superado los dos años para ser considerada como actualizada, esta regla no es rigurosa, más aun si las partes efectuaron la tasación en moneda extranjera, y su valor se ha incrementado. Al respecto, sostenemos que la tasación actualizada debe apreciarse en cada caso conforme a sus particularidades para efectos de evitar abusos por parte de la entidad ejecutante, pero en este caso la Corte Suprema incurre en una motivación insuficiente, pues el solo hecho que se haya fijado el valor del bien en moneda extranjera no es por sí solo válido para considerarlo "actualizado", al existir otros factores en el mercado que determinan el valor de un bien. Así, se evitaría generar un perjuicio económico al ejecutado, pues producto del remate se conseguiría un monto menor al que realmente corresponde.

En la Casación N.o 3147-1998-La Libertad, de fecha uno de junio de mil novecientos noventa y nueve, se resolvió el litigio iniciado por Banco Internacional del Perú (Interbank) contra Industrias Vegetales Sociedad Anónima, sobre ejecución de garantías. En este proceso, se emitió mandato ejecutivo por la suma de ciento tres mil quinientos sesenta y ocho dólares americanos con sesenta y ocho centavos de dólar (capital e interés); sin embargo, se menciona en la resolución casatoria que la ejecutada contradijo señalando que en realidad solo debía la suma de sesenta y siete mil doscientos cuatro dólares americanos con ochenta y ocho centavos de dólar, a raíz de un acuerdo plasmado en Escritura Pública con el acreedor, y este último, al absolver la contradicción, aceptó lo alegado y presentó una nueva liquidación de saldo deudor. Frente a los actuados procesales, la Corte Suprema declara fundado el recurso de casación interpuesto por la ejecutada, nula la sentencia de vista, nulo todo lo actuado e improcedente la demanda, sosteniendo que no existe correspondencia entre el estado de cuenta de saldo deudor que sirvió de base 
para emitir el mandato ejecutivo y el título de ejecución, y aun cuando el Banco haya tratado de variar la liquidación, "no puede admitirse una corruptela procesal como lo que ha sido tolerada por las instancias de fallo". Consideramos que el término usado por la judicatura para anular todo lo actuado y declarar la improcedencia de la demanda, se refiere al abuso de derecho del ejecutante (recordemos la locución latina Abusus non est usus, sed corruptela, que equivale al español como el abuso no es uso sino corruptela); empero, no cita la norma jurídica que sustenta la improcedencia de la demanda, pues no amparó la contradicción ni tampoco existe una causal específica que subsuma lo alegado. Por ello, debe entenderse que es una sanción por la conducta abusiva de la ejecutante al presentar un estado de cuenta de saldo deudor incompatible con el título de ejecución a sabiendas que se adeudaba un monto menor.

En la Casación № 1123-2000-Ica, de fecha veinticinco de octubre del dos mil, se trató el proceso iniciado por el Banco de Crédito del Perú-Sucursal de Ica contra Francisco Alejandro Paredes Morales sobre ejecución de garantías reales. Dentro del proceso, el ejecutado contradijo el mandato ejecutivo sustentándose en la causal de inexigibilidad de la obligación, indicando que ha realizado pagos parciales que no han sido tomados en cuenta en la liquidación. La primera instancia declaró fundada la contradicción e improcedente la demanda, decisión que fue confirmada por la Sala Superior. La Corte Suprema, por su parte, sostuvo que "las instancias de mérito, haciendo uso de la actividad judicial de la valoración de prueba bajo las reglas de la sana crítica, pueden ordenar la deducción de dichos pagos al realizarse el pago de la deuda total a la entidad ejecutante"; de esa manera, declaró fundado el recurso de casación interpuesto por la ejecutante, nula e insubsistente la resolución impugnada y ordenó se expida nueva resolución. En nuestra opinión, la Corte Suprema varía su criterio contenido en la Casación N.o 3147-1998-La Libertad, y ahora decide que se deduzcan los pagos al realizarse el pago de la deuda total a la ejecutante, empero, no solo no ha tenido en cuenta que no existe causal de contradicción sobre "extinción parcial de la obligación", sino que tampoco valora la conducta de la ejecutante al no informar sobre dichos pagos y pretendiendo validarlos en un proceso ejecutivo. Evidentemente, esta es una conducta abusiva que debe sancionarse: si no es con la improcedencia de lo pretendido, mínimamente la imposición de una sanción pecuniaria (multa) y apercibimientos pertinentes para no incurrir en la misma conducta.

En la Casación N.o 1540-98-Lima, de fecha catorce de octubre de mil novecientos noventa y ocho, se advierte las actuaciones del proceso sobre ejecución de garantías reales iniciado por Banco Continental contra Carlos David Malone Salinas. El ejecutado sustentó su contradicción en que el banco ejecutante no cumplió con adjuntar a su demanda la tasación comercial actualizada del inmueble dado en garantía, declarándose infundada en primera y segunda instancia. La Corte Suprema señaló que en la cláusula octava del testimonio de escritura pública (título ejecutivo) las partes convinieron en tasar el inmueble en la suma de setenta y seis mil ochocientos noventa y cuatro dólares americanos, y si bien es cierto el numeral 4 del artículo 720 del Código Procesal Civil regula que no será necesaria la presentación de una nueva tasación si las partes han convenido el valor del bien inmueble, también lo es que ello rige mientras se trate de una valoración actualizada, lo que no ocurrió en este caso por su antigüedad. Se declaró fundado el recurso de casación, nula la sentencia de vista y todo lo actuado hasta el estado en que se provea la demanda según lo considerado. Al respecto, coincidimos en la apreciación de la Corte Suprema, pues es común que la parte ejecutante, abusando del pacto contenido en el título ejecutivo y lo regulado en el artículo 720 numeral 4 del Código Procesal Civil, no presente una tasación actualizada, y por el contrario, pretenda prevalecer una valoración antigua que, por el paso del tiempo, ha ido variando de acuerdo a diversos factores. Sin lugar a dudas, en el supuesto de una subasta pública, el deudor que ha otorgado la garantía real se vería afectado por un valor que no corresponde al de su bien inmueble, conllevando inclusive a que no se pueda cubrir el íntegro de lo adeudado.

En el expediente 00885-2016, tramitado ante el Octavo Juzgado Civil sub especialidad Comercial de la Corte de Justicia de Lambayeque, Scotiabank Perú S.A.A. inició un proceso de ejecución de garantías contra Cristian Bernardo Becerra Carrasco y Sonia María Carrasco Balarezo. El mandato ejecutivo fue por la suma de US\$ $61,325.61$ (sesenta y un mil trescientos veinticinco con 61/100 dólares americanos), más intereses (compensatorios y moratorios); la parte ejecutada presentó su contradicción sustentada en la inexigibilidad de la obligación y nulidad formal del título, y respecto a la primera, indicó que había cancelado la cuota número sesenta y cuatro con fecha trece de octubre del dos mil dieciséis (posterior a la carta notarial que daba por vencidos los plazos y resolvía el contrato), por lo que la obligación no se encontraba vencida al tratarse del pago de una cuota y no de un abono parcial. El A Quo declaró fundada contradicción sustentada en la causal de inexigibilidad de la obligación mediante auto final de fecha veintitrés de abril del dos mil 
dieciocho, exponiendo que "el vencimiento anticipado de todas las cuotas originalmente adoptado por la entidad ejecutante quedó sin efecto atendiendo a su propio comportamiento, pues si bien no está impedida de recibir pagos parciales a cuenta de la obligación adeudada, para mantenerse coherente con su posición, debió imputar estos pagos al total de la liquidación y no a las cuotas originalmente pactadas (...) (pues) al imputar los pagos al cronograma original otorgó nueva vigencia a este, debiendo respetarse sus plazos, hasta que, ante un nuevo incumplimiento de ejecutado, la ejecutante proceda conforme a lo pactado". En su argumentación aplicó la doctrina de los actos propios y el artículo 1362 del Código Civil (buena fe, comportamiento leal y correcto de los sujetos intervinientes). Siendo apelada, la Segunda Sala Civil confirma la decisión de primera instancia mediante auto de vista de fecha diecisiete de septiembre del dos mil dieciocho (con tres votos a favor y dos en discordia). El Colegiado replica la doctrina de actos propios para resolver la litis, pero refiere como cuestión adicional que el pagaré que acredita la obligación fue llenado con fecha anterior a la resolución de contrato (dos años antes), y por lo tanto, no se respetaron los acuerdos adoptados por las partes; este aspecto también fue advertido por el Dr. Carrillo Mendoza en su voto singular, pero calificándolo como ejercicio abusivo de derecho.

Según nuestro criterio, si bien es cierto es discutible que al caso concreto pueda aplicarse la doctrina de los actos propios, pero sí se advierte un ejercicio abusivo de derecho por la entidad ejecutante, al iniciar un proceso de ejecución cuando su comportamiento denotaba la vigencia de la obligación pactada en el contrato de mutuo respectivo. Esto es, tiene el derecho a la tutela jurisdiccional efectiva, siempre y cuando esta se ejerza conforme a su cauce regular; empero, su ejercicio respondió a un ánimo deliberado del cobro íntegro de la deuda, sin considerar que la parte ejecutada venía cumpliendo con pagar las cuotas antes del inicio del proceso, imputándose los pagos al cronograma original (según los vouchers que se adjuntaron en el escrito de contradicción). La ejecutante, con su comportamiento anterior al proceso, denotaba la voluntad de desconocer su propia carta notarial de vencimiento de plazos y resolución de contrato, razón por la cual la pretensión ejecutiva no tenía sustento fáctico.

\subsection{Propuesta de solución}

El artículo 722 del Código Procesal Civil ${ }^{21}$-aplicable solo al proceso de ejecución de garantías- plantea la remisión a las disposiciones generales para contradecir el mandato de ejecución. Entonces, el artículo 690-D de la norma citada contiene las causales específicas para la contradicción que ejercerá oportunamente la parte ejecutada. Si en un proceso de ejecución de garantías reales el ejecutado plantea argumentos alejados a las causales estrictamente contempladas por la Ley procesal, la consecuencia será el rechazo liminar de este acto procesal de defensa.

El sentido de esta regulación se condice con el favorecimiento al ejecutante para ver satisfecha su acreencia en el menor tiempo posible. De manera indirecta también sería positiva para mejorar las condiciones en el otorgamiento de un crédito (por ejemplo, a menor riesgo, menores tasas de interés). Sin embargo, ¿ello justifica válidamente la limitación del derecho de defensa del ejecutado? No negamos que la parte ejecutante, en muchos casos, ejerce con buena fe y honestidad el derecho a la tutela jurisdiccional efectiva para materializar su interés económico. Sin embargo, en no pocos casos puede abusar de este derecho subjetivo, conociendo la situación jurídica del ejecutado a raíz de la perjudicial limitación legal del texto normativo del artículo 690-D del Código Procesal Civil.

En ese contexto, consideramos que el legislador ha regulado específicamente el proceso de ejecución de garantías para favorecer el cobro célere de lo adeudado al acreedor, a costa de dejar casi en la indefensión a la parte ejecutada, lo cual no solo es desproporcionado e irrazonable, sino también inconstitucional.

Desde el punto de vista de la efectividad, el ejecutado no puede defenderse ampliamente lo cual ya es un gravísimo problema que vulnera la Constitución. La situación es aún peor porque la legislación de derecho material, que distribuye y otorga posiciones jurídicas de ventaja y desventaja, permite un número mayor de defensas que la propia legislación procesal. De ello resulta que esta última está construida a espaldas de la primera, cuando en realidad debería reflejarla. (Cavani, 2014, p. 298)

Frente al desequilibrio advertido, no proponemos que la contradicción en el proceso de ejecución de garantías pierda su naturaleza cognitiva sumaria y se reemplace por una de cognición amplia (para sostener, por ejemplo, la nulidad de acto jurídico), pues de ser así ya no tendría mayor razón de ser el proceso ejecutivo.

${ }^{21}$ Artículo 722 del Código Procesal Civil.- "El ejecutado, en el mismo
plazo que tiene para pagar, puede contradecir con arreglo a las 
disposiciones generales". 
Sugerimos que, solo en casos excepcionales y cuando amerite, se pueda alegar el ejercicio abusivo de derecho del ejecutante y este pueda ser declarado y sancionado por el juez. Indistintamente de si corresponde subsumir al ejercicio abusivo de derecho en una de las causales de contradicción o valorarlo en forma aislada, el juzgador tiene el deber de reprimir esta conducta y no guiarse estrictamente por la literalidad de lo regulado en el artículo 690-D del Código Procesal Civil. Si la Constitución no ampara el abuso del derecho, con mayor razón las normas de inferior jerarquía lo repulsan.

Para ello, es necesario establecer dos métodos de interpretación jurídica: extensiva y sistemática. La primera "implica atribuir a un término legal un elevado número, sino el máximo, de acepciones permitidas por su tenor literal, que, y es preciso insistir en ello, no puede ser rebasado en ningún caso" (Ramón, 2014, p. 134). En cambio, la segunda "es la que busca extraer del texto de la norma un enunciado cuyo sentido sea acorde con el contenido general del ordenamiento al que pertenece" (Anchondo, 2012, p. 41). Alejos (2018) refiere que no se puede eludir la interpretación sistemática, pues la norma jurídica no es un mandato solitario ni tampoco denota por sí solo los pilares del ordenamiento jurídico.

El artículo 690-D del Código Procesal Civil debe interpretarse, desde el método extensivo, como una contradicción que comprenda el ejercicio abusivo de derecho, atendiendo a que esta figura resulta de aplicación general en los procesos judiciales (no excluye al proceso de ejecución de garantías), y configura el límite en el ejercicio de derechos subjetivos de naturaleza sustantiva y procesal, situación que no puede ser tolerada por el órgano jurisdiccional. Por su parte, la interpretación sistemática del mencionado artículo conlleva a no restringirse a su literalidad, sino verificarse la complementariedad con otras normas del ordenamiento jurídico, como es el artículo II del Título Preliminar del Código Civil y artículo 103 de la Constitución. Ante las deficiencias en la legislación, el juez no debe recaer en ellas; por el contrario, debe emplear las herramientas con las que cuenta para alcanzar la finalidad concreta y abstracta del proceso. Identificado el ejercicio abusivo de derecho, el juez cuenta con herramientas para eliminar sus efectos. El artículo II del Título Preliminar del Código Civil regula que, al demandarse indemnización o cualquier otra pretensión, "el interesado puede solicitar las medidas cautelares apropiadas para evitar o suprimir provisionalmente el abuso", lo que en buena cuenta significa que el accionante puede solicitar al órgano jurisdiccional la eliminación del abuso de manera provisional hasta la emisión de la decisión judicial definitiva. Sin embargo, tratándose de un proceso de ejecución de garantías reales en donde es el ejecutado quien recibe los efectos negativos del ejercicio abusivo de derecho del ejecutante, es aquel quien debe advertir tal situación en la formulación de la contradicción. Con ello, esta oposición puede ampararse si es que es relacionada con alguna de las causales del artículo 690D del Código Procesal Civil, o en todo caso, el juez puede disponer la nulidad de lo actuado y el archivamiento del expediente.

Asimismo, el juez puede emplear otras sanciones de connotación económica, como la multa a la parte, abogado o apoderado que actúe de mala fe, de conformidad con el artículo 110 del Código Procesal Civil. Con una actuación abusiva también se genera la posibilidad que la parte ejecutante sea demandada por responsabilidad civil ante los daños generados a la parte ejecutada dentro del proceso ejecutivo. ¿Qué ocurre si no se formula contradicción? Cuando la parte ejecutada no se apersona al proceso, o lo hace tardíamente, nada impide que el juez sancione el ejercicio abusivo de derecho, pues en su calidad de director del proceso se le han reconocido legalmente las facultades para sancionar y prevenir este tipo de conductas, salvo que no existan suficientes elementos para determinar esta situación. Por ello, es trascendental superar los formalismos para alcanzar un debido proceso sustantivo, entendido según Gozaini (citado en Blancas, 2014) como "el derecho a la justicia lograda en un procedimiento que supere las grietas que otrora lo postergaron a una simple cobertura del derecho de defensa en juicio. No estaremos hablando más de reglas, sino de principios" (p. 199). Solo de esta manera se estarán salvaguardando los derechos de la parte ejecutada ante el ejercicio abusivo de derecho del ejecutante en un proceso de ejecución de garantías reales.

\section{Conclusiones}

Tal como se ha explicado, el ejercicio abusivo de derecho es un principio general del derecho ligado al principio matriz de la buena fe, consagrado en el artículo 103 de la Constitución peruana y artículo II del Título Preliminar del Código Civil. El acto ilícito se puede presentar en el hecho generador de la relación sustantiva (contrato de mutuo o crédito garantizado con hipoteca) o en el proceso de ejecución de garantías, cuando se pone en funcionamiento el aparato jurisdiccional para solicitudes no conformes al ordenamiento jurídico, o lesivos al orden público y fines del proceso, de tal manera que se pueda predicar un ejercicio abusivo del derecho al debido proceso, en 
específico de las facultades pertenecientes al derecho de acción, configurándose en una situación sin amparo jurídico. En la jurisprudencia nacional y local se aprecian situaciones configurativas del ejercicio abusivo de derecho, como es la realización de las liquidaciones de saldo deudor por parte de las entidades bancarias, tasaciones convencionales desactualizadas, ejecución de una garantía que no fue constituida válidamente, o inicio del proceso ejecutivo cuando la obligación aún estaba vigente, situaciones que fueron sancionadas con el archivamiento del proceso o la nulidad de lo actuado. Consideramos que el desequilibrio en el proceso de ejecución de garantías reales en perjuicio del ejecutado se supera a partir de interpretar el artículo 690-D del Código Procesal Civil desde el método extensivo y sistemático, como una contradicción que comprenda el ejercicio abusivo de derecho, atendiendo a que esta figura resulta de aplicación general en los procesos judiciales (no excluye al proceso de ejecución de garantías), y configura el límite en el ejercicio de derechos subjetivos de naturaleza sustantiva y procesal, situación que no puede ser tolerada por el órgano jurisdiccional. Sin embargo, dado que este principio se caracteriza por su aplicación excepcional (solo si no existe una regla concreta que se pueda subsumir a un caso determinado), corresponderá al juez la valoración de su pertinencia.

\section{Bibliografía}

Alejos, E. (2018, marzo, 06). ¿Sabes cuáles son los catorce métodos de interpretación jurídica? Legis.pe. Recuperado de https://legis.pe/sabescuales-los-catorce-metodos-interpretacionjuridica-legis-pe/

Anchondo, V. (2012). Métodos de interpretación jurídica. Quid luris, Vol. 16, 33-58. Recuperado de https://biblat.unam.mx/hevila/Quidiuris/2012/v ol16/3.pdf

Arango, M. (2016). La causa jurídica de las cláusulas abusivas. Estudios Socio-Jurídicos. Vol. 18(․․1), 241-264. Recuperado de https://revistas.urosario.edu.co/index.php/socio juridicos/article/view/4417/3188

Ariano, E. (2016). La ejecución de garantías reales en el Perú. Antecedentes olvidados y perspectivas de reformas. Docentia et Investigatio. Vol. 18(N.ㅇ1), 79-103.

Ariano, E. (2017). Sobre la función de la (llamada) contradicción del proceso de ejecución. Actualidad Civil. ‥ 37, 5-7.

Artavia, S. \& Picado, C. (2016). El abuso procesal. Master lex. Recuperado de http://www.masterlex.com/descargas/PuntoJuri
dico/2016/Junio/Curso_\%20Abuso_\%20Fraude_ Procesal.pdf

Blancas, C. (2014). El amparo contra resoluciones judiciales. Pensamiento Constitucional, N. 19, 193-206. Recuperado de http://revistas.pucp.edu.pe/index.php/pensamie ntoconstitucional/article/view/12524

Cárdenas, C. (2018, septiembre, 13). El proceso único de ejecución y sus principales características.

Legis.pe. Recuperado de https://legis.pe/proceso-unico-ejecucioncaracteristicas/

Cavani, R. (2014). Incoherencias del proceso de ejecución peruano: causales de contradicción y suspensión de la ejecución. Análisis desde el derecho fundamental a la tutela efectiva, adecuada y tempestiva. Gaceta Civil \& Procesal Civil, N.․ 14, 289-308. Recuperado de https://www.academia.edu/7557721/Proceso d e ejecuci\%C3\%B3n causales de contradicci\%C 3\%B3n_y_suspensi\%C3\%B3n_de_la_ejecuci\%C3 \%B3n

Chiovenda, G. (1954). Instituciones de derecho procesal civil. Madrid, España: Editorial Revista de derecho privado.

De Trazegnies, F. (2005). La verdad construida: algunas reflexiones heterodoxas sobre la interpretación legal. Themis, N.o 51, 31-42.

Escobar, F. (1998). El derecho subjetivo. Consideraciones en torno a su esencia y estructura. Revista lus et Veritas, número 16, 280$298 . \quad$ Recuperado de http://revistas.pucp.edu.pe/index.php/iusetverit as/article/view/15781

Espinoza, J. (2015). Sobre los denominados actos ilícitos dañosos. Revista lus et Veritas, número 51, 116$122 . \quad$ Recuperado de http://revistas.pucp.edu.pe/index.php/iusetverit as/article/viewFile/15655/16092

Fernández Sessarego, C. (1992). Abuso del derecho. Buenos Aires, Argentina: Editorial Astrea de Alfredo y Ricardo Depalma.

Franciskovic, B. (2017). El principio de contradicción, el derecho de contradicción y la mal denominada "contradicción" en el proceso de ejecución. Actualidad Civil. N. 0 37, 29-40.

Gil, J. (2018). Cláusula de vencimiento anticipado. La realidad problemática concerniente a su abusividad (trabajo fin de máster). Universidad de Alcalá, Alcalá de Henares, España. Recuperado de https://ebuah.uah.es/dspace/bitstream/handle/ 10017/33306/definitivo.\%20TFM.\%20clausula\% 
20de\%20vencimiento\%20anticipado.pdf?sequen ce $=1$ \&isAllowed=y

Gozaíni, O. (1995). El desplazamiento de la noción de derecho subjetivo por el de acceso a la justicia sin restricciones (sobre problemas actuales de la legitimación y el proceso judicial). Boletín Mexicano de Derecho Comparado, 1(83). doi:http://dx.doi.org/10.22201/iij.24484873e.19 95.83.3359

Hurtado, M. (2017). La contradicción (rectius, oposición) en los procesos de ejecución. En s.n. (Ed.), El proceso de ejecución de garantías en el derecho peruano, problemas y soluciones (pp.43- 67). Lima: Gaceta Jurídica S.A.

Ledesma, M. (2010). Reglas actuales del proceso de ejecución en el Código Procesal Civil. En M. Torres (Ed.), Manual de Actualización Civil y Procesal Civil (pp.35-81). Lima: Gaceta Jurídica S.A.

Loutayf, R. (2004). El abuso procesal. "Anales" de la Academia Nacional de Derecho y Ciencias Sociales de Córdoba, tomo XLIII, 01-18. Recuperado de http://www.riaej.com/sites/default/files/Abuso \%20Procesal\%20Argentina.pdf

Loutayf, R. (2015, 17 de junio). Abuso del derecho. Jurisprudencia Argentina. Recuperado de www.acaderc.org.ar/abuso-delderecho/at download/file

Mejorada, M. (2004). La propiedad y el bien común. Revista foro jurídico, número 03, 128-131. Recuperado de http://revistas.pucp.edu.pe/index.php/forojuridi co/article/viewFile/18345/18588

Miranda, D. (2016). Hacia una delimitación del abuso del Derecho a partir de sus fundamentos. Actualidad jurídica Uría Menéndez, N. 44, 31-40. Recuperado de https://www.uria.com/documentos/publicacion es/5144/documento/art02.pdf?id=6820

Missé, A. (5 de mayo de 2019). Los jueces españoles empiezan a archivar desahucios tras la sentencia europea. El País. Recuperado de https://elpais.com/economia/2019/05/04/actual idad/1556967094_109510.html

Moisset, L. (2002). El abuso del derecho. En Tinti, G. (Ed.), El abuso en los contratos (pp. 23-43). Buenos Aires, Argentina: Editorial Ábaco De Rodolfo Depalma.

Monroy, J. (1996). Introducción al proceso civil. Bogotá, Colombia: Editorial Temis.

Morales Hervias, R. (2008). Situaciones jurídicas subjetivas. Advocatus, 0(019), 323-360. https://doi.org/10.26439/advocatus2008.n019.4 78

Obando, R. (2017). El abuso de derecho y la buena fe: principios generales del derecho. Actualidad Civil, N. 0 37, 91-99.

Pabón, C. \& Mora, A. (2014). Límites al ejercicio abusivo del derecho de retracto. Inconstitucionalidad en la sobreprotección del consumidor. Revista Contexto, número 41, 67-86. Recuperado de https://revistas.uexternado.edu.co/index.php/co ntexto/article/view/3853/4108

Picó I Junoy, J. (2003). El principio de la buena fe procesal. Barcelona, España: J.M. Bosch Editor.

Picó I Junoy, J. (2012). El derecho procesal entre el garantismo y la eficacia: un debate mal planteado. Revista Derecho y Sociedad, número 38, 274-280. Recuperado de http://revistas.pucp.edu.pe/index.php/derechoy sociedad/article/view/13126/13737

Posada, C. (2015). Las cláusulas abusivas en los contratos de adhesión en el derecho colombiano. Revista de derecho privado. N. 29, 141-182. Recuperado de https://revistas.uexternado.edu.co/index.php/d erpri/article/view/4328/5081

Ramón, E. (2014). Interpretación extensiva y analogía en el derecho penal. Revista de derecho penal y criminología, N.o 12, 111-164. Recuperado de http://e-

spacio.uned.es/fez/eserv/bibliuned:revistaDerec hoPenalyCriminologia-2014-125010/Interpretacion extensiva analogia.pdf

Rubio, M. (2008). El título preliminar del Código Civil. Lima, Perú: Fondo Editorial de la Pontificia Universidad Católica del Perú.

Ruiz, N. (2006). La teoría de la imprevisión y su desarrollo internacional. Derecho y Realidad. Vol. 2(N.o 7), 153-165. Recuperado de https://revistas.uptc.edu.co/index.php/derecho realidad/article/view/5183/4216

Sevilla, P. (2017). Medida cautelar fuera del proceso y su formalización. Actualidad Civil, N.@ 37, 49-60.

Trigiani, A. (2017). El abuso procesal. Aequitas. Vol. 11 (N. $\quad$ 27), 1-15. Recuperado de https://p3.usal.edu.ar/index.php/aequitasvirtual Larticle/view/4321/5360

Zatti, P. (2005). Las situaciones jurídicas (V. Contreras Granda, \& G. Mendoza Del Maestro, Trads.). (2005). Revista Jurídica del Perú, 64, 357-389. Recuperado de: https://es.scribd.com/document/265686441/Sit uacion-Juridica-Zatti 
Zuzman, S. (2005). La buena fe contractual. Themis, N. $51,19-29$. 